\title{
THE BEGINNINGS OF COPYRIGHT LAW IN MACAU
}

But what is the fate of man? Endowed with a heart whose wickedness is as great as his spirit; crime lies at the side of genius. Of all sublime inventions have men abused.

(Andrade 1835, p. 5: my translation).

\section{INTRODUCTION}

Macau has all the ingredients for a valiant copyright history, just waiting to be told. ${ }^{1}$ A cosmopolitan centre of knowledge production where the first Western printing press in China was set up, equipped with one of the earliest copyright laws in East Asia, and praised for its fight against piracy during its post-colonial years. And yet it is not easy to tell this tale as a 'memory of the Macanese feats against the pirates' - following the title of the 1835 book from which I borrowed the opening quote. Mirroring the various discontinuities that the reader will find in the following pages; technological innovation, grand cultural landmarks and laws seem to appear in all the wrong places in this historical timeline. Thus the story that will be told here can perhaps be best described as a trail of official papers whose connection to social life is extremely hard to pin down. If, for Sherman and Bently (1999) 'much of the history of intellectual property law can be seen as one of the law attempting ... to capture the phantom' (p. 59), here the law itself is the phantom constantly escaping the historian's grasp.

In one sense, this history begins in the second half of the nineteenth century when, in 1869, the Portuguese Civil Code of $1867^{2}$ - with its chapter on literary and artistic labour (do trabalho literário e artístico) articles 570-612 - was extended across the Portuguese colonial empire. ${ }^{3}$ Still, in at least two other senses this is a false start. On the one hand, a history that does not account for its own pre-history seems unable to explain its object (Pottage \& Sherman, 2013). On the other, the historical significance of this statute should not be assumed from the outset, particularly considering that, as Hespanha (1995) points out, there was generally a very low level of enforcement of official law in the Portuguese overseas territories (p. 4). To use a common strategy, I shall try to begin where others have found a promising start: the printing press (eg. Feather, 1994; Patterson, 1968; Goldstein, 2003; Samuels, 2000). Thus the first part of this paper will deal with the beginnings of printing in Macau, drawing extensively on a short essay written in 1963 by Macanese intellectual José Maria ('Jack') Braga. As we shall see, this is a tale of two beginnings anchored in the history of two artefacts: the Jesuit Press (1588-1620) and 
the British East India Company Press (1815-1834). In the second and third parts of this paper I shall turn to the beginnings of copyright law in Macau and, borrowing from Braga, this too will be a tale of two beginnings anchored in the local history of two foreign artefacts: the decree that extended the Portuguese Civil Code of 1867 to the colonies (Decreto 18.11.1869) and the 1998 Special 301 Report of the United States Trade Representative 4 that catalysed unprecedented levels of legislative and administrative action in the enforcement of copyright. By juxtaposing these two local histories, with their four disconnected beginnings, my aim is to examine the law's imagined potentiality - in its ability to control social behaviour - and the symbolic role it played in the construction of an image of Macau that was refracted in the external centres of power that have shaped and continue to shape its copyright law. ${ }^{5}$

\section{Gutenberg in the 'Rome of the East'}

The appealing image of the printing press as an agent of change (Eisentein, 1979) has left its mark on copyright historiography. There are several good reasons to resist its seductive force (Bracha, 2013; Bowrey, 2007) and yet I am not compelled to withdraw from it altogether. If, as Oren Bracha (2013) claims, a version of copyright's history as "a path leading from "Gutenberg to the Celestial Jukebox" or as a series of technological developments and the legal reactions to them' (p. 45) has captured the popular imagination, there is a potential for critique in engaging the narrative and taking it to a less familiar territory.

\section{1 THE JESUIT PRESS}

So let us begin this path with the setting up of a Western printing press with movable metal types at the Jesuit College of Macau in 1588. This is believed to have been the first Western printing press in China, both in terms of type and geographical origin (Matos, 2011, p. 726; Braga, 1963, pp. 30-31). But, during its short stay in Macau, this press played only a minor role in the construction of Macau as a 'centre of science and education' (Pires, 1991, p. 15) or as the 'bridgehead of Christianity in the Far East' (Teixeira, 1991, p. 43).

Macau's true relevance was instead that of a powerful linguistic centre, a 'unique place where it was possible, at the same time, to learn Portuguese, Latin, Chinese and Japanese, where there are Asian and European masters teaching beginners' and advanced courses for these languages.' (Barreto, 2006, p. 314: my translation) During these early years Macau functioned not only as the base for the Jesuit mission in Japan - providing a safer place than Nagasaki, where missionaries had been facing a more hostile environment since 1587 (Witek, 1997, p. 19) - but also as a training camp for European Jesuits who came there to learn Chinese in their quest 
to evangelise the Middle Kingdom profiting from a growing community of Christianised Chinese. (Barreto, 2006, p. 335; Tang, 2016, pp. 56 ff.)

That Macau had achieved such a prominent cultural role during its so-called 'golden age' of trade (1560-1640) (Cremer, 1991; Barreto, 2006, p. 347) is hardly surprising given that trade and religion had always been two closely related aspects of Portuguese maritime expansion. Tellingly, as historian Luís Filipe Barreto (2006) points out, the earliest extant Portuguese document that is known to have been written in Macau (1555) and where the name Amacau occurs for the first time ( $p$. 17 ) is a letter by the famous merchant Fernão Mendes Pinto to the Rector of the Jesuit College in Goa, in which he mentions an encounter with a high-rank Jesuit Priest in transit from Guangzhou (pp. 20-28).

Jesuits and merchants built a close and mutually beneficial partnership. With their erudition and linguistic expertise, Jesuits acted as translators in the dealings with local merchants and local officials but also as intermediaries that, as Charles R. Boxer (1988) put it, 'had the right contacts in high places' (p. 12). Portuguese merchants, on their part, offered their services to the Company by allowing Jesuit priests to travel safely between Lisbon, Goa, Macau and Nagasaki, providing them shelter and donations, as well as a share in the lucrative Sino-Japanese trade which constituted a valuable source of income for the mission (Boxer, 1988, p. 39 ff.; Barreto, 2006, pp. 89 ff., pp. 136 ff.) The Jesuits also played an important internal role, acting as the de facto judicial power, in what the Portuguese residents were concerned, during the early years of the settlement (Barreto, 2006, p. 112) and playing a decisive role in the internal politics of the city and in its relation to the colonial administration in Goa, later in the century (circa 1590-1660) (Penalva, 2007).

This commercial, political, religious and diplomatic alliance, contributed to Macau's status as an essential post in the Portuguese Eastern trading routes (Cremer, 1991), as well as a platform for the diffusion of Christianity, receiving the title of 'Rome of the Far East' (Teixeira, 1991, p. 43).

So here is the puzzle: Macau stood as an important centre of knowledge, it provided a platform for the gathering of information (on lands, seas and cultures that were to a great extent still unknown to Westerners), for education, for exchanges between different languages and cultural traditions, and for the attempt to introduce Christianity in the East. It also had the relevant technologies (typography ${ }^{6}$ and xylography ${ }^{7}$ ) and access to channels to disseminate the knowledge produced therein. However, this did not seem to translate into the emergence of a publishing powerhouse. During its first stay in Macau the printing press set up at the Jesuit College produced only two books for the Jesuit Mission in Japan, before it was moved to Nagasaki in 1590 where it was put to more significant use (Boxer, 1993, 
pp. 189-198). After Christianity was banned in Japan by leasyu in 1614 (Boxer, 1993, pp. 314-317, 491-492)

the Nagasaki press at all events was packed and sent (via Manila) to Macau. Here, except for the Arte Breve of 1620, it seems to have been left to rust unused in the godowns; since for one reason or another the art of printing from movable types never found favour in China until the nineteenth century, and the local Jesuits were satisfied with engravings from woodblocks as of old. (Boxer, 1993, p. 198)

This can be partly explained by the fact that some of the knowledge produced in Macau was not primarily destined to be distributed locally. And since people and manuscripts travelled if not quicker at least cheaper than large quantities of printed materials, some of the books originated (in terms of knowledge or manuscripts) in Macau were printed elsewhere: Nagasaki in Japan where the printing press was set up between 1590 and 1614, the Guangdong province where many Jesuits settled, and Europe. 8

The second part of the explanation is more complex and a bit harder to pin down. Part of the knowledge produced in Macau was highly important for the commercial success and political survival of local elites who were not keen on seeing it disseminated. Barreto's (2006) detailed account of the cultural landscape in Macau during the sixteenth and seventeenth centuries sheds some light on it.

As Barreto (2006) explains 'cultural products and producers [were] intimately connected to the logic and the pace of the maritime trade' (p. 276: my translation). These dealt almost exclusively with topics and problems that were of interest to the 'trading and missionary oligarchies that hegemonised the life and the sense of the port city' (p. 277: my translation) namely seamanship (navigation, cartography and ship building), clerical matters, and also linguistics, geography and anthropology which were essential disciplines both to the merchant and to the religious missions. And since the success of both depended to a great extent upon the knowledge not only of the land and of the sea but also the Japanese and Chinese ways ('o saber das coisas da China e do Japão', p. 298) it was fundamental to control access to these sources, and hence exclude potential rivals. As Barreto (2006) puts it 'while these texts [were] aimed at an addressee and at a cultural universe that lie [d] beyond Macau, they target[ed] specific and directed readers and readings, seeking to remain inscrutable to other potential addressees' (p. 298: my translation) something which was achieved by the choice of idiom and medium (oral, handwritten or printed).

Unsurprisingly the preferred medium to record this kind of information was handwriting. This helps explain why the bulk of textual production, outside the strictly evangelical, was epistolary and handwritten (Barreto, 2006, pp. 298 ff.), 
particularly information dealing with seamanship (including cartography) which, according to Barreto (2006) was of a strictly manuscript and evolving nature - slowly copied, revised and updated by hand, often based on Chinese printed sources (pp. $306 \mathrm{ff}$.). ${ }^{9}$ Perhaps the most striking example of the use of handwriting as a medium to collect, record and control the dissemination of practical information gathered in Macau comes from the 'Vocabulário Português-Chinês' (1580?-1588?). ${ }^{10}$ Thought to be the first Chinese dictionary in a Western language, it remained in manuscript form - with potentially different versions circulating between Macau and Zhaoqing and was not published either on xylographic or typographic form (Barreto, 2006, p. 316, $318 \mathrm{ff}.) .{ }^{11}$ This raises the likely hypothesis, advanced by Barreto (2002) that it was more of 'a tool of collective use that was always being added to' ( $p$. 118) than a book - much less a dictionary - in the modern sense.

\subsection{THE PROTECTION OF AND FROM IDEAS IN EARLY MACAU}

The a particular dynamic in the production and circulation of written texts emerged in Macau, stood in contrast with the situation in Portugal where privileges ${ }^{12}$ and censorship ${ }^{13}$ were the two key political apparatuses employed to control the printing press up to the 1820s.

Printing is thought to have begun in Portugal in 1487, about a decade and a half after it had reached Spain. ${ }^{14}$ Still, there are no records of printing privileges granted during the age of the incunabulum (i.e. before 1501). The use of privileges relating to printing seems to have only begun in the first years of the sixteenth century, and even then in a somewhat limited fashion (Armstrong, 1990, p. 8). One of the most often mentioned privileges by Portuguese copyright scholars is the one granted in 1537, by a Letter of Privilege of King D. João III, to writer Baltazar Dias, by which the latter acquired the exclusive monopoly to the printing and selling of his own works (Pereira, 2008, p.52; Biblioteca Nacional, 1994, p. 15; Rebello, 1973, p. 559; Leitão, 2011 , p. 23). And while this literature almost invariably emphasises the fact that it had been granted to an author rather than a publisher; the letter of privilege contains the rather more interesting statement that Dias's previous works, some of which had already been printed, had been 'inspected and approved' (vistas e aprovadas) as shown in a 'public deed' (instrumento público) offered alongside his petition. Further adding that

if he is to make any works that touch upon matters of our holly faith they shall not be published without first being seen and examined by Mestre Pedro Margalho ${ }^{15}$ and if after being seen and examined by him they are found not to speak of things that shall not be spoken of he shall make of that his certificate with which certificate I shall be pleased that such works be printed and not otherwise. ${ }^{16}$ 
As historian Graça Almeida Rodrigues (1980, pp. 15 f.) points out, this privilege is granted at a pivotal moment, a year after the Inquisition had been officially set up, thus giving rise to the first institutional model of censorship in the country (15361768 ) and to a specific form of censorial bureaucracy. ${ }^{17}$ As Rodrigues (1980, pp. 14 24) explains, this new model, as it developed in time, was composed of three layers of pre-emptive censorship (i) papal, through the General Council of the Holly Office; (ii) episcopal, through the local bishopric; and (iii) royal, through the Desembargo do Paço (after 1576); together with repressive censorship carried out through customs and port controls, as well as by visits to ships, public and private libraries, bookshops and printing houses. As Bethencourt (2009) aptly summarises, the whole 'cycle of book production, distribution and possession' was kept under control (pp. 223 f.). ${ }^{18}$

As we have seen, in early Macau, it was the medium used to record and distribute information, rather than the request for privileges, that seems to have played the decisive role in controlling its circulation. This was essentially the case of information concerning seamanship, but also of information on local developments, and to some extent local customs. As for religious materials, the dynamic was completely opposite. The goal was to disseminate them as much as possible, and the difficulties laid exactly in the political and cultural obstacles that these missionaries found in such foreign lands. In any case, further research on the rivalry between various religious orders may reveal a more nuanced picture highlighting internal tensions dealing with the exclusive use of typography by the Jesuits. ${ }^{19}$

While nominally most of the privileges granted in Portugal during this period might have included the colonies and overseas possessions of the Portuguese crown, these would possibly have limited practical significance in Macau. In order to fully grasp this, we will need to learn a bit more about the political and administrative makeup of the city and its ambiguous relation to the Portuguese and Chinese empires, that came to be forged in the early days of the Portuguese settlement.

According to the traditional Portuguese narrative, the Portuguese were allowed to establish a permanent settlement in the small isthmus bordering the greater Guangdong region in 1557, as a reward granted by the Chinese emperor for their efforts in defeating the pirates that infested the South China Sea (Jesus, 1902, pp. $18 \mathrm{ff}$.). ${ }^{20}$ That this narrative is essentially an elaborate fiction to legitimise Portuguese colonial ambitions over the territory has been made clear in the historical work of Anders Ljungstedt (1836, ch 1), ${ }^{21}$ Swedish Consul in Macau with close ties to the Swedish East India Company in Guangzhou (Gunn, 1996, p. 3). As Barreto (2006) clearly shows, the Portuguese establishment in Macau was a gradual and largely informal process mainly led by prominent Portuguese merchants with strong connections to Asia by marriage and familial links, as well as by a continuing partnership with Chinese merchants and local Guangdong authorities (pp. 96-108).22 To that extent, it is perhaps futile to search for the origins of Macau - as a political 
construct - in official bureaucratic and diplomatic sources, for as Tereza Sena (2008) argues

Macau's origins as a port city lay in a private Luso-Asian project strongly directed towards the lucrative but forbidden trade between China and Japan. This project involved multiple interests and brought together high-ranking Chinese officials and authorities, Jesuit priests, and Western and Eastern merchants linked to transoceanic routes and involved in Asian mercantile networks. ( $p$. 89: footnotes omitted)

Such project thus required both flexibility and ambivalence - anchored in a refined way of conducting informal diplomacy (Monteiro, 2011, ch 7) - to keep it from falling under the weight of any of these two powerful, yet distant, imperialistic forces, while still keeping access to the channels opened up by them (Sena, 2008, pp. 88 ff.; Wu, 1999, ch 2; Barreto, 2006, pp. 220 f.; Pina-Cabral, 2002, pp. 1-4; Santos \& Gomes, 1998, p. 491). ${ }^{23}$

In its early years, the governance of Macau was exercised with a high degree of autonomy, arguably the highest it ever had during its history, as the city was effectively controlled by an oligarchy of wealthy merchants - embodied in the Senado ${ }^{24}$ - that was closely aligned with the Jesuit cultural elite (Barreto, 2006, pp. 136-167; Penalva, 2007).

The network of interests that connected these two elites, made it unlikely that those with the skill and technology to disseminate information would do so in a way that would be contrary to the merchants' interests. Also, the fact that maritime trade was by far more lucrative than publishing and bookselling seems to have given no reasons for the commercial elite and for pirates as well, to venture into the Jesuits' domain of culture and spirituality.

Tellingly, the first time the Inquisition (which was set up in Goa in 1560 having jurisdiction over Macau) showed signs of worry about books in Macau - rather than Jews and New Christians - was precisely after the Dutch attempt to invade Macau in 1602 and 1603. As Miguel Rodrigues Lourenço (2011) notes 'the Goa inquisitors ordered the governor of the Chinese bishopric ... to collect and deliver any works written in Dutch that might be in the possession of the city's residents (moradores)' (p. 474: my translation) obviously fearing that the Reformist movement could be thus introduced in the city.

\subsection{THE BRITISH EAST INDIA COMPANY PRESS: A SECOND BEGINNING}

While in Portugal, royal and ecclesiastic authorities maintained a tight grip in the production of printed materials until the $1820 \mathrm{~s}^{25}$ the arrival at Macau of the English 
Protestant missionary Robert Morrison in 1807 would mark the second beginning of printing in Macau after an interregnum of almost two hundred years (Braga, 1963, pp. 37-41).

The intrusion of this foreign body into the metabolism of the city would in time create a couple of thorny diplomatic incidents. ${ }^{26}$ The first involved a raid by 'about twenty-five Chinese soldiers' at the 'East India Company's printery at Macao' in 1817 (pp. 65-69), the second ended with Robert Morrison moving his Albion Press to Guangzhou after a row with Portuguese Catholic priests in 1833 (pp. 103-109).

But what makes these two events remarkable is indeed their exceptionality. When the first of these incidentes occurred, Morrison had already been active publishing texts in Chinese and English since 1811, first by xylography and then by typography with a British printing press sent from London and arriving at Macau in 1814 (Braga, 1963, pp. 51-64). This may appear particularly striking given that preaching Christianity in China was prohibited by Imperial law (Braga, 1963, p. 66; Su, 1996, p. $50)$, and that printing in the Portuguese overseas colonies and dominions was strictly forbidden (Braga, 1963, p. 41; Guedes, 2010, p. 46). As Braga clearly shows this could not have been made possible without both Portuguese and Chinese authorities having turned a blind eye on Morrison's activities. ${ }^{27}$ It seems highly probable that local authorities placed more importance in securing the commercial benefits accruing from the activities of the British East India Company and avoiding diplomatic rows with Britain, than zealously enforcing the prohibitions stemming from the respective imperial centres. ${ }^{28}$ A similar dynamic may help explain the lack of any relevant incidentes regarding Protestant publications between 1817 and 1833, despite the lack of compliance with the Chinese ban that was still in force (Hao \& Wang, 1980, p. 177) and Portuguese legislation that - albeit reformed after the liberal revolution of 1820 - still required the submission of texts to pre-emptive censorship and the registration of any printing presses operating in the city. (Braga, 1963, p. 104, 79)

These incidentes are also instructive for the subtle way in which they were resolved. According to Braga (1963, pp. 66-68) the 1817 incidente seems to have arisen when one of Morrison's Chinese type-cutters sent a sheet of the EnglishChinese dictionary that was being prepared at the Company's press to the local Chinese magistrate in Macau who felt compelled to report it to his superior in the Casa Branca in Qianshan. ${ }^{29}$ If we strip off Braga's account from the misguided references to Portuguese sovereignty over Macau, ${ }^{30}$ we get the following picture. The report could hardly have caused great surprise, but lack of action might have put the Mandarin of the Casa Branca in a delicate position vis-à-vis the Viceroy of Guangdong and Guangxi and perhaps even with central powers in Beijing. A raid was conducted at the East India Company Press in Macau, but not before word had been sent through Chinese merchants connected to the Company in Guangzhou. The 
presence of Chinese soldiers in a non-Chinese residence, must have caused some embarrassment to the Portuguese authorities who seem to have protested, but not too vehemently, to the Viceroy in Guangzhou. Adding to this series of theatrical gestures, the Select Committee of the Company pleaded for the Viceroy's clemency and quickly took steps to avoid further trouble with Chinese authorities. By replacing their Chinese workforce with Portuguese and Bengali labour, the Company gave Chinese authorities a reason for refraining to interfere under the excuse of lack of jurisdiction. ${ }^{31}$ The following words of Reverend Walter Henry Medhurst written in Macau in 1838, and quoted by Braga, offer a vivid description of the state of affairs:

[I]nto the dwellings of Europeans, the Chinese never enter, not even to apprehend offenders of their own nation. Thus, a foreigner has only to rent the dwelling of a Portuguese citizen, and that house is his castle, where he may print books, in any quantities, without danger of interference from the mandarins; he may even have a Chinese school, and retain a number of writers and teachers about him, so long as these do not put themselves in the way of the native police. A missionary who intends carrying on Chinese printing, in Macao, should ... employ principally foreign servants, so that no natives may be implicated in vexatious proceedings, on his account. (W.H. Medhurst (1838) China: its state and prospects, London, p. 283, quoted in Braga, 1963, p. 70 fn 81)

This suitable arrangement was again upset in 1833, this time due to a complaint raised by a senior member of the local Catholic Diocese to the Governor of Macau, against a sermon Morrison had published in his Albion Press, which had recently arrived from London. Again, we see official law being invoked - in this case Morrison's failure to register his new printing press - to disrupt the unofficial compromise that governed the everyday workings of the city. Seeking to find a diplomatic resolution to the incidente, the Governor liaised with the Select Committee of the East India Company in order to have them exercise their 'jurisdiction' over Morrison. Sensing the Governor's weak response, the Capitulary Vicar of Macau sought the intervention of the Senado, forcing the Governor to insist with the Company's Select Committee. Instructions were sent to Morison to discontinue his printing at Macau, who - not without grumbling at the Committee's failure to stand up for his cause - relocated the press to Guangzhou (Braga, 1963, pp. 103-109).

These two incidentes stand as exemplary illustrations of the complex dynamics of the local administration of the city and of the subtle diplomacy that marked the accommodation of its internal contradictions. But this is not to say that official law had no role to play in the governing of local affairs; only that it stood as one among many other sets of protocols that had to be constantly balanced, negotiated and 
sometimes circumvented. A feature that, as we shall see, maintained its relevance even during Macau's colonial period.

\subsection{A NEW PRINT CULTURE}

In the intervening years - between Morrison's arrival and the incidente of the Albion Press - the Portuguese political and constitutional makeup suffered a series of radical changes. In the wake of the Napoleonic invasions (1807-1810) the Portuguese Crown fled to Brazil, leaving the former metropolis as a de facto British protectorate. It was against this backdrop that, in 1820, liberals seized power and quickly set up a Constituent Assembly (Cortes Gerais e Extraordinárias da Nação Portuguesa) that would produce the first Portuguese Constitution of 1822 (nicknamed Constituição Vintista). ${ }^{32}$

Freedom of expression ('a livre comunicação dos pensamentos') not subject to pre-emptive censorship ('censura prévia') was among the basic rights recognised in the Constitution (art. 7) ) $^{33}$ and extended to Portuguese citizens across the empire, including the 'establishment' (estabelecimento) of Macau (arts. 20, iv and 21). ${ }^{34}$ The promise would, however, fail to materialise as the abolition of pre-emptive censorship was being constantly postponed in hope that both radical and reactionary passions would eventually cool off (Tengarrinha, 2013, pp. 347-356). Still, the new liberal impetus had a very tangible repercussion in Macau with the arrival of 'a new Portuguese printing press and fonts of type' (Braga, 1963, p. 42) in 1822. ${ }^{35}$ The newly arrived press was immediately put to use issuing what is thought to be Macau's first periodical A Abelha da China (12 Sept. 1822 - 28 Aug. 1823), a hybrid form of official gazette and partisan pamphlet (Guedes, 2010, p. 46), dutifully “"Visado pela censura": passed by the censorship' (Braga, 1963, p. 79). Closely aligned with the liberal faction, this short lived publication would be at the centre of an incidente that culminated in the public burning of its final issue, when the power shifted towards the conservatives who renamed it Gazeta de Macau (Jan 1824 - Dec. 1826) (Guedes, 2010). ${ }^{36}$ The press would again change hands in 1827 , after the Gazeta closed down, when it was lent to the College of St. Joseph and from which several publications came out (Braga, 1963, p. 81).

The closing down of the Gazeta opened up an eight year void in terms of local periodicals for the Portuguese readership, but coincided with the publication in Macau of an English language newspaper The Canton Register (Nov 1827-? 1843) (Braga, 1963, p. 88). ${ }^{37}$ Other English language periodicals such as The Canton Miscellany (June 1831-May 1832), The Chinese Repository (May 1832 - Dec 1851), and The Evangelist and Miscellanea Sinica (1833), would come out of presses that migrated between Macau and Guangzhou (Braga, 1963, pp. 88-101). By 1833, according to a report in The Chinese Repository quoted by Braga, there were five 
English printing presses in China, two of which operating in Macau (Braga, 1963, pp. $112 \mathrm{ff}$.) alongside the Portuguese press set up at the College of St. Joseph. Adding to this landscape, there was a new surge of Portuguese periodicals between 1834 and 1845 (Gomes, 1973, p. 197). Agnes Lam (2011) also points out to the publication in Macau of the Tsu-wan-pien (Apr-Oct 1833) by Robert Morrison as 'the first Chinese newspaper ... published in China' and 'the first [Chinese] periodical printed in a Western printing press with movable types' (p. 733: my translation). ${ }^{38}$

By the 1840s, the opening up of Guangzhou to foreign trade and the British settlement in Hong Kong ( Wu, 1999, ch 3.2.2-3) lead to the relocation of most foreign typographic activity away from Macau (Braga, 1963). At the same time, according to Guedes (2011), the tightening up of censorship between the 1840s and 1870 s, seems to have affected the Portuguese periodic press (p. 730).

It is perhaps telling that Braga's (1963) narrative of the beginnings of printing in Macau ends more than thirty five years before copyright had reached the territory, similarly Agnes Lam's (2016, non vide) recent monograph on Macau press history ends in 1840. This raises the hypothesis of a disconnection between copyright and print culture in Macau, which might point to another direction in an analysis of the role of copyright law in Macau's history.

\section{FROM LITERARY PROPERTY TO COLONIAL COPYRIGHT}

The entry into force of the 1867 Portuguese Civil Code across the Portuguese colonial empire in July 1, 1870 - through Decreto 18.11 .1869 (art. 2) - marks the official beginning of colonial copyright in Macau. The lack of specificity of this event - it was neither a specific extension of copyright law, but a part of a larger legislative initiative; nor was it specific to Macau - raises doubts over its true significance. Thus, in order to make sense of this arrival, it will be necessary to devote some lines to the long process that led to the institution of copyright in Portugal, as well as to the specific context of the assertion of Portuguese colonial dominance over Macau.

When copyright law arrives, Macau's golden years both in terms of commerce and culture were long gone. The city's prospects were, by then, in rapid decline given the loss of its privileges regarding China's foreign trade and its inability to compete with British Hong Kong. As a consequence, economic activity turns primarily to the sordid coolie trade (Cheng, 1999, p. 31), gambling (Godinho, 2012), opium and prostitution as well as some industrial and banking activities (Gunn, 1996, ch 5). Against this backdrop it is hard to believe that the institution of copyright had any relevant effects in Macau's cultural landscape. Still, or so I will claim, the successive and ritualistic extensions of copyright legislation to the territory, retain a central importance in the reflection of a certain idea of empire, throughout the nineteenth and twentieth centuries. 


\subsection{THE TROUBLED PATH TO LITERARY PROPERTY IN PORTUGAL}

The first statutory mention to literary property in Portugal came oddly enough in a law regulating the freedom of press (Decreto de 4 de Julho de 1821) which, in its article 2, declared that 'the faculty to publish any original or translated book or writing is the author's or translator's own property for his life, being held by his heirs and successors for ten years' (my translation) adding in article 3 that infringers would lose all copies in favour of the proprietor unless their number would not amount to one thousand, in which case they would have to pay the difference.

However, this statutory regulation of the press would not resist the absolutist backlash of May/June 1823 that became known as the Vilafrancada. (Tengarrinha, 2013, pp. 392 ff.).This was a remarkably complex period in Portuguese political (Birmingham, 2003, ch 4) and constitutional (Hespanha, 2012) history, with two constitutions (Vintista 1822, and Carta Constitucional 1826) ) $^{39}$ came in and out of force, dancing to the flow of the struggle between progressives and conservatives, in a movement that was only interrupted by periods of absolutism and by the shortlived constitution of 1838 (Setembrista). ${ }^{40}$

Within this complex legislative framework, pre-emptive censorship was maintained (Tengarrinha, 2013, pp. 405 ff.) and references to literary property scrapped altogether. These would only reappear under art. 23(4) of the 1838 constitution (Setembrista) that resulted from the liberal victory against the absolutist forces in the Civil War (1828-1834).

But this reappearance of literary property in the Setembrista Constitution would prove to be another false start. In January 27, 1842 after a conservative coup lead by Costa Cabral, the Carta was restored (Hespanha, 2012) - alongside draconian censorship measures that became popularly known as 'lei dos rolhas' (lit. 'cork law' $^{41}$ (Tengarrinha, 2013, pp. 667-671). These 'intervening political commotions' as Almeida Garrett (1851, p. 690: my translation) would later call them, also meant that the ongoing discussion of a literary property bill - of which Garrett had been the main promoter in the lower house of the Portuguese parliament in $1839^{42}$ - had reached a dead end (Biblioteca Nacional, 1994, p. 16). As with the 1821 law on the freedom of press, literary property appeared closely connected to freedom of expression, most clearly in the passionate speeches of Almeida Garrett, of which the following words addressed to the lower house of Parliament before presenting his bill are a clear illustration

We owe this law to the men of letters, to the sage: they are hefty creditors of freedom. We have broken, yes, the censorial scissors of the Desmbargo do Paço that so often mutilated the beauty of their thoughts; yes, we have put out the fires of the Rossio ${ }^{43}$ that, at 
other times, devoured works of a lifetime, when not life itself in the same barbaric sacrifice ... We owe them, thus, reparation: let us give it to them with this law. (Diário da Câmara dos Deputados (1839) no. 35. Sessão de 18 de Maio, pp. 570-571: my translation)

This entanglement seems to have informed its quick acceptance by progressives, ${ }^{44}$ but also the conservative resistance that hindered Garret's bill.

With the fall of Costa Cabral in the wake of a military coup in 1851 and under the special powers granted to the Queen in its aftermath, Garrett's bill bypassed the upper house of the Parliament, and finally made it into law through a dictatorial Decree of July $8,1851 .{ }^{45}$ This happened only after a Convention with France - which Garrett himself had negotiated and signed on behalf of the Portuguese state on April 12,1851 - had been ratified on June $12,1851,46$ making it a remarkable early example of policy laundering (Hosein, 2004, p. 189).

History would, however, painfully reveal that the entanglement between literary property and freedom of expression, that continued in the text of the 1867 Civil Code (arts. 570 and 576), was indeed a very fragile one. ${ }^{47}$ Nevertheless, Garrett's concern with the country's international reputation and the framing of copyright protection as a civilizational advance would echo throughout the years as it was repeatedly used as an argument justifying further amendments to copyright law. Again, it is worth quoting Garret's hyperbolic address in support of his 1839 bill at some length:

Forced until now by its stupid governments to drag among the rear guard of civilisation ... the Portuguese nation now liberated and regenerated, shall move with a different verve. And through the voice of its representatives it shall let Europe know that although having been vilified, it still deserves, or has come to again deserve, the place of honour it once had in the early campaigns of civilisation when it marched ... alongside the vanguard of all lights.

Such great example given by such a small nation, such generous initiative in so grand an issue, undertaken by such a vilified people, will exceedingly benefit all Europe and put to shame her great powers who shall lag behind Portugal, small and poor but as generous as it ever was. Haven't we discovered the East for the world's commerce? Did we not take civilisation and Christianity to the backlands of Africa, haven't we discovered and populated half America forming new empires, new nations out of a tiny corner of the Iberian peninsula (Diário da Câmara dos Deputados (1839) no. 35. Sessão de 18 de Maio, p. 570: my translation). 
Perhaps the clearest example of this continuity comes from the preamble of the 1927 Copyright Act ${ }^{48}$ that, among other things, established perpetual copyright. There, the recognition of property over intellectual works is seen as a hallmark of 'a higher phase of progress of the law and of human civilisation' alongside the hopeful remark that 'the principle of perpetuity is ... gaining track' internationally (p. 902, p. 905: my translations).

\subsection{COlOnial Macau}

When the 1851 act came into force in Portugal, Macau had entered a new moment in its legal and political history, having become a de facto colony of the Portuguese empire. While it would be impossible to conduct a detailed analysis of this transformation here, I hope a brief outline of the political history of Macau in the aftermath of its so-called 'golden years' (1560-1640) might help set the stage for the introduction of colonial copyright in Macau.

The suspension of trade with Japan (1640; Barreto, 2006, p. 179) marked the beginning of the long decline of the local bourgeoisie, making the city's internal affairs more vulnerable to interventionist policies by Chinese authorities and attempts of centralisation by the Portuguese Crown (Wu, 1999, ch 2, ch 3.1-3) thus upsetting the tenuous equilibrium that lied at the basis of Macau's 'autonomy' (Afonso \& Pereira, 1986, pp. 30-33; Gunn, 1996, pp. 37-38; Sena, 2008, pp. 90-91).

On the other hand, the events surrounding the first opium war (1839-1842) turned the ambiguity that had proven so beneficial in the past into a potential liability (Wu, 1999, ch 3.2-3; Mendes, 2013, p. 11). European imperialistic incursions into China heightened the need, felt by Portuguese authorities, to secure the political status of its presence in Macau as well as the opportunity to extend its power over the territory. This was initiated by a coup lead by the then Portuguese Governor of Macau, Ferreira do Amaral in 1849. In a series of authoritative measures - and against opposition from the Senado - Amaral expelled local mandarins, lead a campaign of dispossessions and broke off with the system of mixed Sino-Portuguese jurisdiction that had marked the life of the city until then (Pina-Cabral, 2002, p. 51-66), thus subjecting Macau to de facto colonial rule. The new political status of Macau was officially recognised in the 1887 Treaty of Beijing, ${ }^{49}$ but even then leaving a series of questions unanswered (Wu, 1999, ch 4.23; Fei, 1996, ch 8).

\subsection{COLONIAL COPYRIGHT AND THE SYMBOLIC SURVIVAL OF THE EMPIRE}

Despite the unclear status of the 1851 Act in Macau, ${ }^{50}$ the lasting influence of Garett's defence of authors helped frame copyright both as property and as a 
civilizational advance, two factors that might explain its inclusion in the 1867 Civil Code. And it is in a similar 'civilising' gesture that the Civil Code is extended across the legal space of the empire (Silva, 2015). Thus we see Macau receiving one of the earliest copyright laws in the Far East ${ }^{51}$ but only as a tiny fragment of the grander monument of legal codification that the new liberal governments were actively constructing in the metropolis.

It seems thus safe to assume that the beginnings of copyright law in Macau had little to do with local needs. As far as I was able to tell, this new legislation had little practical impact in the territory, particularly considering that there seems to have been no special legislation regulating the registration and deposit of works published in the colonies. In the absence of special provisions, registration and deposit had to be done in Lisbon, according to the general rule (art. 603 and 604 of the 1867 Civil Code). ${ }^{52}$ Adding to this, protection was restricted to Portuguese authors publishing in Portuguese territories (art. 576), while foreign nationals would receive protection under a rule of reciprocity (art. 578). This, in effect, excluded not only a great part of the Chinese population residing in Macau, but also the growing Macanese diaspora.

The extension of copyright law to Macau, with such lack of regard for local conditions is only the first in a series of oddities that punctuate its history. The curious position of Macau regarding the Berne Convention ${ }^{53}$ and the Universal Copyright Convention 1952 is a case in point.

Despite having included its colonies when acceding to the Berne Convention (Berlin Act 1911) (54 $^{4}$ was not until 12 August 1999 that the Convention was finally extended it to Macau, ${ }^{55}$ only a few months before the handover of the territory to the People's Republic of China. According to art. 26 of the Berlin Act, the extension to the colonies would only come into effect upon the submission of a written declaration to the Government of the Swiss Confederation, and later to all other member states, stating the intention to include them. The Portuguese Government seems not only to have failed to submit such declaration, ${ }^{56}$ but also to have failed to publish the Decreto 18.3.1911 in Macau's Official Gazette. This latter mishap probably meant that the changes this Decree introduced to the 1867 Civil Code essentially the extension of the list of protectable subject matter - never came into force in Macau. Thus it seems that between 1911 and $1930^{57}$ some categories of works (e.g. photography and architecture) were protected in Portugal, but not in Macau. The Berne Convention (Brussels Act 1948) would eventually come to be published in the Official Gazette on September 10, $1955^{58}$ but once again, as Cabral (1999) states, Portuguese authorities failed to notify the intention to include its colonies, apparently not binding Macau (p. 123). Similarly, Macau only became bound by the Universal Copyright Convention (1952) - which was ratified by the Portuguese state on December 25, 1956; and December 26, 1979 after the Paris 
Amendment of 1971 (Biblioteca Nacional, 1994, p. 42) - in late 1999, after a notification by the Portuguese Government on July 23, 1999 (Cabral, 1999, p. 23).

This apparent lack of attention to the local copyright regime would once again create two awkward situations which accidentally meant, at least on paper, that copyright owners would have continued to enjoy in Macau protection for works that had already entered the public domain in Portugal. The background to these episodes is set by a curious decision to establish perpetual copyright in the Portuguese 1927 Copyright Act (arts. 15, 16) to all works that had not yet entered the public domain (art. 15, 3). ${ }^{59}$ This law was extended to Macau in $1930 .{ }^{60}$ Perpetuity would be repealed with the 1966 Copyright Code ${ }^{61}$ that set the term back to fifty years post mortem (pma) (art. 25; cf. art. 5791867 Civil Code). Under the transitional regime, works which had benefited from perpetual protection under the 1927 Copyright Act would not fall into the public domain until twenty five years after the publication of the new Code (art. 37, 21966 Copyright Code), that is by January 1, 1992. The absence of any special rules governing the extension of the 1966 Copyright Code to Macau ${ }^{62}$ raises the question as to whether the twenty five year extension would be counted from the year of publication of the new code in Portugal (1966) or in Macau (1972). This six year gap probably meant that the extension would only lapse in Macau on January 1, 1998, granting copyright owners six years extra of protection in Macau for works whose authors had died on or before December 31, 1941. ${ }^{63}$ This also meant that works falling in the public domain in Portugal, under the new fifty year term, between 1992 and 1997 would still be protected in Macau until January 1, 1998.

The plot thickened when in 1979 a new law ${ }^{64}$ repealed section 2 of art. 37 of the 1966 Copyright Code, therefore subjecting all works to the fifty year pma rule. This meant that all works whose authors had died on or before 1929 entered the public domain by January 1980, while all others would be subject to the fifty year term. That this law was not extended to Macau is understandable given that, by then, Macau was already in a process of transition and had ceased to formally be a colony. Still, during this transitional period colonial laws continued to apply to the territory meaning, in this particular case, that works that had entered in the public domain in Portugal by 1 January 1980 would still enjoy a further eighteen years of protection in Macau. The lack of a local initiative to pass a similar act speaks to lack of attention to such matters.

While there is certainly a lot still to be uncovered in examining the practical significance of copyright law in Macau, this series of absences, delays and incomplete transpositions seem to suggest that the function of these laws was not primarily one of governing behaviour. Taken within the broader ambit of Macau's colonial history, this story seems to suggest that copyright law's significance was more symbolic than practical. As we have seen, the period of colonial 
administration, starting roughly around 1849 - within which copyright law arrives at Macau - appeared at a time when Macau had lost its strategic position either as a centre of commerce or as a platform for cultural Westernisation. As Pina-Cabral (2003) aptly puts it 'for metropolitan Portugal, the practical importance of Macau was not economic but rather as a symbol of imperial might in a time of significant struggles within Europe for the status of colonial power.' (p.7: my translation) Thus Macau seems to have remained for most of its colonial period a political 'dead soul', worth more for nurturing the Portuguese imperialist imagination than for any immediate benefits it might have brought.

And it is through this prism that a history marked almost exclusively by successive extensions of metropolitan legislation, begins to reveal a particular function that might have escaped at a first glance. The imperfections of this ritualistic practice of extending official law across the empire suggest that they meant much more to the metropolis, than they did to the colony. It is precisely the apparent lack of concern for the local impact of these laws that reveals the history of colonial copyright in Macau as one of empty assertions of colonial authority designed to keep the idea of empire alive in the metropolitan imagination. In that regard there is perhaps nothing special about copyright law per se, but it is precisely its banality that helps us make sense of this history of absence.

\section{Negotiating the tRANSITION: POST-COLONIAL COPYRIGHT}

The picture of Macau as a political dead soul of the Portuguese empire, helps explain both a lack of concern for the local copyright regime, and the odd character of the Portuguese colonial administration. As Anthony R. Dicks (1984) wrote in the late 1960s, 'Macao's status as a part of Portuguese territory takes on some of the character of a legal fiction' (p. 92) precariously sustained on account of a strategic Chinese policy keen on maintaining the status quo while not shying away from making its strength felt from time to time (Fernandes, 2008; Mendes, 2013, pp. 1418, pp.24-25; Santos \& Gomes, 1998, pp. 41-51; Pereira, 1995, ch 4-5; Dicks, 1984; Wu, 1999, ch 4.6.2).

The establishment of official diplomatic relations between the two nations, in 1979, paved the way for the negotiations on the 'Question of Macau', concluded with the signing of a Joint Declaration in $1987 .{ }^{65}$ The date for the handover was set for December 20, 1999, when Macau officially became integrated into the People's Republic of China as a Special Administrative Region (SAR). This was made possible by an abrupt change of regime in Portugal, as the 25 de Abril revolution (1974) put an end to more than forty years of fascism and triggered the process of decolonisation in Africa and Timor, leaving Macau as 'a problem left over from history' (Mendes, 2013, p. 29). As a result, Macau's official status changed from 
colony ${ }^{66}$ to 'territory under Portuguese administration' (art. 5, 4 of the 1976 Portuguese Constitution). ${ }^{67}$ A new Estatuto Orgânico de Macau (the basic regulation of the political and administrative structure of Macau) ${ }^{68}$ was passed in the same year, granting local authorities a high degree of political autonomy. (Afonso \& Pereira 1986, pp. 37 ff.; Wu 1999, ch 5.1.2).

These final years of Portuguese administration were marked by spectacular incidentes of gang violence (Pina-Cabral, 2002, pp. 213-218; 2003; Clayton 2009, pp. 59-98) as well as large scale piracy, now of a very different sort than the one preoccupying Andrade (1835) in the opening quote. Concerns over piracy dictated a series of important legislative and administrative initiatives and inaugurated a new period in Macau's copyright history.

\section{1 THE INCIDENTE OF THE SPECIAL 301}

In 1979 American trade magazine Billboard published a series of articles on piracy in South-East Asia. In its Hong Kong piece Macau was portrayed as a safe haven for counterfeiters, Steve Neary, director of the International Federation of the Phonographic Industry (IFPI) Asian and Pacific Regional Office, describes the situation in Macau:

Piracy is rampant ... I even came across a church which had a little stall out in front where they sold their own pirated cassettes - in the name of the church, of course. Our head office in London has been making representations to the Portuguese government, but Portugal has no copyright legislation at all. The same applies to its colonies and provinces. We did get somewhere when the government said that it would be bringing in copyright legislation, but unfortunately, that government didn't last long. (Ebert, 1979, p. SA-28, emphasis added)

Although this statement (echoed in Billboard, 1980 and Faison, 1998a) comes across as utterly uninformed, in a more charitable reading we should understand it as referring to entrepreneurial copyright (droits voisins in the Continental tradition) particularly the protection of record producers. Indeed, Portugal did not ratify the 1961 Rome Convention until 1999, ${ }^{69}$ and had only introduced legislation offering protection to producers of phonograms in $1980{ }^{70}$ and videograms in $1985 .{ }^{71} \mathrm{Macau}$, no longer officially a colony, and enjoying legislative autonomy passed its first local statute dealing with copyright aimed at repressing the unauthorised sale of phonograms and videograms in November $1985 .^{72}$

With the date of the handover soon approaching, Macau became one of the founding members of the World Trade Organisation in 1995. With it, came the need 
to revise the copyright legislative framework - still based on the 1966 Portuguese Copyright Code and the local Lei n. $04 / 85 / M$ - to put it in line with international requirements (Cabral, 1999, pp. 123-124; 2010, p. 208). These changes to the copyright system did not occur immediately as Macau enjoyed a moratorium regarding the TRIPs Agreement (article 65) until 2000 (Cabral, 1999, p. 123) which would roughly coincide with the handover and with it the need to enact local statutes to replace old colonial laws given the uncertainty over whether legislation enacted in Portugal and extended to Macau would 'survive'. ${ }^{73}$

While work on the drafting of what would become Macau's own Copyright Code ${ }^{74}$ was well under way, another incidente precipitated a series of changes. In 1998, Macau was given Priority Watch List status in the United States Trade Representative Special Report 301.

Pressure for immediate and effective changes to crack down the emerging illicit trade on copyright infringing material began mounting around 1997. This is well attested in various articles published on Billboard between 1997 and 2000 that voiced the concerns of the IFPI (Burpfee \& Clark-Meads, 1997; Burpfee, 1997a; 1997b; 1998; Tsang, 1998; White, 1998; McClure, 1998; Clewley, 1998; Hughes, 1998; Mok, 2000; Fuller, 2000; Masson, 2000).

This shift of attention was invariably presented as resulting from a dislocation of pirate operations from the Mainland and Hong Kong to Macau - not only in Billboard but in The Economist (1998), The New York Times (Faison, 1998a; 1998b), The Independent (Vines, 1998), and Forbes (Tanzer, 1998). This became the official version among U.S. industry representatives (Richardson, 1998, p. 37; Berman, 1998, p. 39) and government officials (Lehman, 1998, pp. 21, 29; Papovich, 2000, pp. 14 f.) and was inscribed in the IIPA report for $2001 .{ }^{75}$

However, it seems difficult to disentangle this narrative from the industry's own lobbying strategy that, in tandem with the diplomatic initiatives of the USTR, had helped bring out important changes to the legislative and enforcement mechanisms in place in both China (Mertha, 2005, pp. 126-133; Zhang, 2007) and Hong Kong (The Law Reform Commission of Hong Kong, 1993; Woods, 2003). How effective those changes have actually been in tackling piracy in those territories is hard to attest, giving conflicting accounts on this point (Yu, 2000, pp. 133-135; Woods, 2003); but the theme that runs through the official version is a tale of successful co-operation between stake-holders and governments in chasing out pirates from China and Hong Kong that eventually sought refuge in Macau; placing the territory at the top of the IFPI's priorities, and subsequently in the Special 301 list.

The picture of Macau as an 'enormous problem that is completely out of control' (Burpfee, 1998; Faison, 1998a): a 'lawless' (Bureau of East Asian and Pacific Affairs, 2001) 'black hole' (Tsang, 1998, p. 12) 'controlled by triads' (White, 1998, p. 70) who 
'run the show' (Mok, 2000, p. 70) and where 'no effort is being made to quell the booming [piracy] industry' (Faison, 1998a) due to 'the lack of the rule of law' (Metalitz, 1998, p. 50), underplayed the initiatives of Macanese authorities (Mok, 2000, p. 70; WTO, 2001, p. 21) and completely disregarded the available legal mechanisms to secure enforcement through civil litigation.

Although the perceived lack of protection seems to have had some actual basis, this had to do in part with the right-holders' own reluctance to use available judicial channels. A strategy that seems to conform to the agenda laid out by Juin-Chan Giouw, IFPI's regional director for South East Asia and China, at the 1998 Asian Music Conference where he is reported to have said:

that the Asian industry should not try to fight pirates directly but instead concentrate its efforts on encouraging government bodies to combat the spread of illegitimate product. "We need to change the idea that [anti-piracy] legislation is there for the industry ... It's there for the government to implement." (McClure, 1998, p. 66)

Threats of international trade sanctions were taken very seriously by local authorities and we witness what, in the grand scheme of things, is nothing less than an explosion in legislative activity in what had been such an arid area of the law for more than one hundred years.

The first piece of legislation to be enacted regulated the commerce and industry of videograms, phonograms and computer programs. ${ }^{76}$ Its aim was, in the wording of the preamble, to provide an 'important step towards the immediate repression of piracy' (my translation).

However, these changes did not achieve their goal as Macau maintained Priority Watch List in the following year. ${ }^{77}$ Consequently, a new piece of legislation was enacted to tackle the problem ${ }^{78}$ now clearly acknowledging in its preamble that the issue of large-scale piracy was creating serious difficulties in trade relations.

The situation seems to have improved and in the following year Macau's status was lowered to Watch List ${ }^{79}$ but the situation only seems to have come under control around 2001, when the newly created Customs Services took administrative enforcement away from the hands of Macau Economic Services. ${ }^{80}$ As a result, in Macau left the Watch List in $2002{ }^{81}$ and since then was signalled as an example to other jurisdictions in the region for its strict control on optical disc manufacturing. ${ }^{82}$

\subsection{SPECULATIONS ON AN UNTOLD HISTORY}

This new period in Macau's copyright history, developing under the spectre of piracy, stands within a complex network of internal and external dynamics that mark 
the realignment of political, economic and social structures in a region that was on the brink of a radical change.

A serious examination of copyright's place within this wider network is yet to be done, but for the sake of this rough historical sketch it seems pertinent to signal some of the ways in which this tale of pirates and pirate hunters, to borrow a phrase from Adrian Johns (2009), intersects with the much publicised 'triad wars' that erupted between 1997 and 2000 and marked the final years of Portuguese administration.

While it seems highly unlikely that these 'wars' - tied as they were to the far more lucrative casino-related activities (Pina-Cabral, 2002, pp. 209-219; Lo, 2008, ch 4; Viana, 2000) - had anything to do with the 'piracy sector' or the external pressures threatening this 'industry'; the image of lawlessness emerging in this period seemed ripe for mobilisation in discourses attempting to establish causal relations between copyright infringement and organised crime

From the idea that local triads controlled piracy in Macau (Burpfee, 1998; White, 1998; Mok, 2000, p. 48; Fuller, 2000; Masson, 2000, p. 78) ${ }^{83}$ - put forward essentially by the IFPI, and reproduced elsewhere (Faison, 1998a; 1998b); to the use of Macau as a 'case study' in the entertainment industry's effort to link piracy to organised crime (IFPI, n.d.; p. 12; Teverton et. al., 2009, p. 66; Valenti, 2003a, p. 54; 2003b, pp. 174 f.) years later, it seems hard to deny that the eruptions of gang violence in the streets of Macau coloured the accounts of Macau's piracy problem.

To be sure, that there might have been a link between the type of large scale production and distribution of unlicensed materials and local triads makes for safe bet, given what we know about the political economy of Macau's underworld (Santos \& Gomes, 1998, ch 17). Still, as Karaganis (2011) has shown, one thing is to point out the unsurprising 'points of intersection between the pirate economy and wider illegal and quasi-legal arrangements of the informal economy' (p. 37); and quite another to establish 'systematic links between media piracy and more serious forms of organized crime.' (p. 38) In the more specific case of the triads operating in Hong Kong and Macau, a second degree of care must be taken not to overestimate the level of stability, organisational hierarchy and central planning in triad organisations (Guedes, 1991; Chu, 2000, pp. 135-137; 2005).

The exact terms of the connection between piracy and local triads remains, thus, rather obscure. but perhaps a more interesting project would be to trace the concrete modes in which the theatrical aesthetics of the eruptions of violence that characterised the various episodes of the 'triad wars' (Pina-Cabral, 2002, p. 215) greatly exploited by the Hong Kong media (Pina-Cabral, 2003, p. 9) - have contributed to the projection of an image of Macau image that reinforced the piracy narrative both locally and abroad. Doing so would contribute greatly to solving the 
paradox that seems to lie at the heart of Macau's change from 'problem' to 'example' for other jurisdictions in the region.

That is, if the ties between piracy and organised crime were indeed well knotted it seems highly unlikely that the progress praised in the Special Reports (2001 onwards) resulted from legislative and administrative actions alone, without new protocols of cohabitation having been negotiated between the relevant authorities and the main 'stakeholders'. ${ }^{84}$ Macau's success story may turn out to be partly explained by the alignments and realignments of forces that gave rise to and resulted from this 'last incidente in Portuguese-administered Macao' (Pina-Cabral, 2002, p. 219). If this proves to be the case, this may constitute fertile ground for an investigation into copyright's economic significance in the region as well as on local protocols for its enforcement. ${ }^{85}$

If, on the other hand, Macau's success story can be credited to legislative and law enforcement activities alone, this may suggest that the tale of piracy and organised crime may was grossly exaggerated, reproducing and reinforcing the discursive construction of the "Asian pirate" so eloquently critiqued by Liang (2011).

Even if these questions must be left hanging for now it seems clear that the incidente of the Special 301 stands as a clear illustration of how diplomacy has been the prime means for copyright enforcement by international copyright owners in Macau. Civil litigation was, as far as I could tell, inexistent during the period between 1985 and 2001 as diplomatic pressure over local authorities - leading to legislative changes as well as criminal and administrative enforcement activities (WTO, 2001) - seems to have been a more cost-effective solution.

\section{CONCLUSION}

The gaps and limitations of the history that I have attempted to sketch here should by now have become - I hope not too painfully - apparent. Leaving the author's talents aside, this is due partly to the broad scope of the paper and partly with a general lack of literature on the history of Macau copyright law and on Portuguese colonial intellectual property law. In spite of that, I hope the paper has done enough to prompt the curiosity of those interested in the legal, cultural and political history of Macau.

To that extent, this paper could be read as an opening gambit that suggests that the history of copyright law in Macau between 1869 and 2001 can be divided into two periods. A first period, coinciding roughly with the colonial administration of Macau, and marked by routine extensions of metropolitan law. And a second period, during the transition to post-colonial rule, marked by local legislative production and administrative enforcement usually prompted by external actors. The demarcation between the two periods comes from what I have tried to identify as the primary 
function these laws played in their local context, as well as in the way they reflected back to the centres of power that shaped them, to a greater or lesser extent.

The imperfection that punctuated the ritualistic extension of metropolitan law to the colony, in the first period, suggests a key concern with projecting an idea of imperial sovereignty back to the colonial centre that outshined any practical role these laws might have had on the ground. Still, I was wary that this history of absence might portray Macau as something of a cultural terra nullius where copyright law had little chance to grow roots. For that reason I spent some time, in the first part of the paper, discussing the beginnings of printing in Macau in order to dispel such a reading, while at the same time questioning commonly held assumptions over the role of copyright law. To that extent, I hope to have illuminated different sets of protocols that governed the activities of printers in the city that bore little resemblance to copyright law.

The second period, is marked by a much clearer effect on the ground, despite a near absence of civil litigation. This suggests a stronger normative role but mainly as grounding the diplomatic leverage of external actors to pressure administrative and criminal enforcement. The striking narrative and chronological parallels between the incidente of the Special 301 Report and the famous 'triad wars', may suggest interesting points of contact between these two incidentes. Teasing out this connection could help greatly in assessing the symbolic role played by copyright during these years.

\section{ACKNOWLEDGEMENTS}

I would like to thank Fiona Macmillan, Jose Bellido, Gonçalo Cabral and Luís Pessanha for the invaluable comments to earlier versions of this paper. All errors and omissions are my very own 


\section{REFERENCES}

Afonso, R. \& Pereira, F. G. (1986). The political status and government institutions of Macao. Hong Kong Law Journal, 16, 28-57.

Andrade, J. I. (1835). Memoria dos feitos macaenses contra os piratas da China: e da e entrada violenta dos inglezes na cidade de Macau. Lisboa: Typografia Lisbonense.

Armstrong, E. (1990). Before copyright: the French book-privilege system 1498-1526. Cambridge, UK: Cambridge University Press.

Ascensão, J. O. (1997) A situação da propriedade intelectual em Macau. Retrieved from:

http://www.fd.ul.pt/Portals/O/Docs/Institutos/ICJ/LusCommune/AscensaoJoseOliveir a4.pdf

Barreto, L. F. (2002). Review of 'Dicionário Português-Chinês' by John W. Witek (ed.). Bulletin of Portuguese-Japanese Studies, 5, 117-126.

Barreto, L. F. (2006). Macau: poder e saber-séculos XVI e XVII. Lisboa: Presença.

Berman, J. (1998, May 21). hfa51834.00: Intellectual property rights: the music and film industry: Hearing before the Subcommittee on International Economic Policy and Trade, 105th Cong. 51 (statement of Jason Berman, Chairman, RIAA, pp. 38-41). Retrieved from: http://commdocs.house.gov/committees/int/rel/

Bethencourt, F. (2009). The Inquisition: a global history, 1478-1834 (J. Birrell, Trans.). New York, NY: Cambridge University Press.

Biblioteca Nacional. (1994). Direito de autor em Portugal: um percurso histórico. Lisboa: Instituto da Biblioteca Nacional e do Livro/Direcção-Geral dos Espetáculos.

Billboard (1980, April 5). Macau still piracy haunt, 76.

Birmingham, D. (2003). A concise history of Portugal (2nd ed.). Cambridge, UK: Cambridge University Press.

Bowrey, K. (2007). Fertile ground: law, innovation and creative technologies. In F. Macmillan (Ed.), New directions in copyright law (Vol. 5, pp. 162-196). Cheltenham: Edward Elgar.

Boxer, C. R. (1988). The great ship from Amacon. Macau: Instituto Cultural.

Boxer, C. R. (1993). The Christian century in Japan 1549-1650. Manchester: Carcanet Press.

Bracha, O. (2013). Copyright history as history of technology. WIPO Journal, 5, 4553.

Braga, J. M. (1963). The beginning of printing at Macao. Studia, 12, 29-137.

Retrieved from: http://library.umac.mo/ebooks/b31042132.pdf.

Bureau of East Asian and Pacific Affairs (2001, March 27). U.S.-Macau Policy Act Report: Required by Section 204 of P.L. 106-507. Retrieved from: https://20012009.state.gov/p/eap/rls/rpt/4048.htm

Burpfee, G. \& Clark-Meads, J. (1997, April 12). CD plant growth tops IFPI's agenda: labels alarmed by rise in production capacity. Billboard, pp. 45, 50. 
Burpfee, G. (1997a, May 31). China piracy efforts lauded at MIDEM Asia. Billboard, pp. 1, 105.

Burpfee, G. (1997b, September 13). First Hong Kong raid nets CDs, equipment: new law facilitates seizures in burgeoning pirate market. Billboard, pp. 10, 104.

Burpfee, G. (1998, April 11). Piracy war shifts in SE Asia: new laws in HK; crackdown in China. Billboard, pp. 6, 100.

Cabral, G. (1999). A localização do direito de autor. Boletim da Faculdade de Direito da Universidade de Macau, 7, 121-128.

Cabral, G. (2003). Macau. In C. Heath (Ed.), Intellectual property law in Asia (pp. 151171). London: Kluwer Law International.

Cabral, G. (2010a). Computer programs in Macau copyright law. In J. Godinho (Ed.), Studies on Macau civil, commercial, constitutional and criminal law (pp. 207-228). Hong Kong: Lexis Nexis.

Cabral, G. (2010b). Direito de autor na internet: das medidas tecnológicas de protecção à suspensão do acesso. Boletim da Faculdade de Direito da Universidade de Macau, 29, 227-236.

Caniato, B. J. (2004). Macau, história e cultura. In H. Garmes (Ed.), Oriente, engenho e arte: imprensa e literatura de língua portuguesa em Goa, Macau e Timor Leste (pp. 115-136). São Paulo: Alameda.

Cardinal, P. (2008). Macau: the internationalization of an historical autonomy. Boletín Mexicano de Derecho Comparado, 122, 637-689.

Carnaxide, V. (A. B. de Sousa) (1918). Tratado da propriedade literária e artística: direito interno, comparado e internacional. Porto: Renascença Portuguesa.

Cheng, C. M. B. (1999). Macau: a cultural Janus. Hong Kong: Hong Kong University Press.

Chow, K.-W. (2007). Reiventing Gutenberg: woodblock and movable-type printing in Europe and China. In S .A. Baron, E. N. Lindquist \& E. F. Shelvin (Eds.), Agent of change: print culture studies after Elizabeth L. Eisenstein (pp. 169-192). Amherst, MA: University of Massachusetts Press.

Chu, Y.K. (2000). The triads as business. London; New York, NY: Routledge.

Chu, Y.K. (2005). Hong Kong triads after 1997. Trends in Organized Crime, 8(3), 5-12. doi:10.1007/s12117-005-1033-9

Clayton, C. H. (2009). Sovereignty at the edge: Macau and the question of Chineseness. Cambridge, MA; London: Harvard University Asia Center.

Clewley, J. (1998, September 19). Thailand uses new legal tool in battling pirates. Billboard, 73.

Colmey, J. (1998, April 20). Tales from the Dragonhead. Time, 51(15). Retrieved from: https://archive.li/ECKNa 
Cremer, R .D (1991). From Portugal to Japan: Macau's place in the history of world trade. In R. D. Cremer (Ed.), Macau: city of commerce and culture: continuity and change (2nd. ed., pp. 23-37). Hong Kong: API Press.

Cruz, G. B. da (1967). O movimento abolicionista e a abolição da pena de morte em Portugal (resenha histórica). In G. Braga da Cruz (1981) Obras esparsas, vol. Il: estudos de história do direito: direito moderno. 2.a parte (pp. 27-243). Coimbra: Coimbra Editora.

Dicks, A. R. (1984). Macao: legal fiction and gunboat diplomacy. In G. Aijmer (Ed.), Leadership on the China Coast (pp. 90-128). London; Malmö: Curzon.

Ebert, H. (1979, March 17) Hong Kong [Supplement: Australia, New Zealand, Southeast Asia: an expanding music marketplace]. Billboard, pp. SA8; SA28-SA30.

Eisenstein, E. (1979). The printing press as an agent of change: communications and cultural transformations in early-modern Europe (2 Vols.). New York, NY: Cambridge University Press.

Faison, S. (1998a, March 28). China turns blind eye to pirated disks. The New York Times. Retrieved from:

http://www.nytimes.com/1998/03/28/business/international-business-china-turnsblind-eye-to-pirated-disks.html

Faison, S. (1998b, June 24). Clinton in China: cleanup; Chinese cracking down on the pirating of CD's. The New Yok Times. Retrieved from:

www.nytimes.com/1998/06/24/world/clinton-in-china-cleanup-chinese-crackingdown-on-the-pirating-of-cd-s.html

Feather, J. (1994). Publishing, piracy and politics: an historical study of copyright in Britain. London: Mansell.

Fei C. (1996). Macao 400 years. (Wang Y., Trans.). Shanghai: Shanghai Academy of Social Sciences.

Fernandes, M. S. (2008). How to relate with a colonial power on its shore: Macau in the Chinese foreign policy, 1949-1965. Bulletin of Portuguese-Japanese Studies, 17, 225-250.

Ferraz, J. M. (2003). Algunos apuntes históricos sobre el nacimiento de la propriedad intelectual en Portugal. Documentación de las Ciencias de la Información, 26, 199231.

Ferreira, J. D. (1871). Código civil portuguez: annotado (Vol. 2). Lisboa: Imprensa Nacional. Retrieved from: http://purl.pt/12145.

Fuller, C. (2000, March 18). Asia: economic crisis helps make piracy a "critically bad" situation. The IFPI tries to replicate recent enforcement successes. Billboard, 62.

Ganea, P. (2005). Copyright history. In P. Ganea, C. Heath \& H. Saitô (Eds.), Japanese copyright law: writings in honour of Gerhard Schricker (pp. 1-10). The Hague: Kluwer International. 
Garrett, A. (1851, June 29). Representação à Rainha. In T. Braga (Ed.), Obras completas de Almeida Garrett, vol. II: prosas (pp. 689-691). Lisboa: H. Antunes. Retreived from: https://archive.org/details/obrascompletasde02alme.

Godinho, J. (2007). Macau business law and legal system. Hong Kong: Lexis Nexis. Godinho, J. (2012). A history of games of chance in Macau: Part I - Introduction. Gaming Law Review and Economics, 16, 552-556.

Goldstein, P. (2003). Copyright's highway: from Guttenberg to the celestial jukebok (Rev. ed.). Standford, CA: Stanford University Press.

Gomes, L. G. (1973). Bibliografia macaense. Macau: Imprensa Nacional.

Guedes, J. (1991). As seitas: histórias do crime e da política em Macau. Macau: Livros do Oriente.

Guedes, J. (2010). Abelha da China, A. In M. A. Espadinha (Ed.), DITEMA: Dicionário temático de Macau (Vol. 1, pp. 45-47). Macau: Universidade de Macau.

Guedes, J. (2011). Imprensa de Macau: Imprensa periódica do século XIX a 1980. In M. A. Espadinha (Ed.), DITEMA: dicionário temático de Macau (Vol. 2, pp. 730-732). Macau: Universidade de Macau.

Gunn, G. C. (1996). Encountering Macao: a Portuguese city-state on the periphery of China, 1557-1999. Boulder, CO: Westview Press.

Hao Y.-P \& Wang E.-M. (1980). Changing Chinese views of Western relations, 184095. In J. F. Fairbank, \& K-W Liu (Ed.), The Cambridge history of China (Vol. 11, Part 2, pp. 142-201). Cambridge, UK: Cambridge University Press.

Hao Z. (2011). Macau: history and society. Hong Kong: Hong Kong University Press. Herculano, A. (1851). Da propriedade litterária e da recente convenção com França ao Visconde d'Almeida Garrett. In A. Herculano (1873) Opúsculos, tomo II: questões públicas (pp. 54-112). Lisboa: Viúva Bertrand. Retrieved from: http://purl.pt/718. Hespanha, A. M. (1995). Panorama da história institucional e jurídica de Macau. Macau: Fundação Macau.

Hespanha, A. M. (2012). O constitucionalismo monárquico português: breve síntese. Historia Constitucional, 13, 427-526.

Hosein, I. (2004). The sources of laws: policy dynamics in a digital and terrorized world. The Information Society: An International Journal, 20, 187-199. doi:10.1080/01972240490456854

Hughes, O. (1998, April 3). Piracy draws protest in Hong Kong. Billboard, 57. IFPI (International Federation of the Phonographic Industry) (n.d.). Music piracy: serious, violent and organised crime. London: IFPI.

Jesus, C. A .M de (1902). Historic Macao. Hong Kong: Kelly \& Walsh. Johns, A. (2009). Piracy: the intellectual property wars from Gutenberg to Gates. Chicago, IL: Chicago University Press. 
Karaganis, J. (2011). Rethinking piracy. In J. Karaganis (Ed.), Media piracy in emerging economies (pp. 1-73). New York, NY: Social Science Research Council.

Lam, A. S.-L. (2011). Imprensa de Macau: Imprensa periódica chinesa. In M. A. Espadinha (Ed.) DITEMA: Dicionário temático de Macau (Vol. 2, pp. 733-739). Macau: Universidade de Macau.

Lam, A. S.-L. (2016). The beginning of the modern Chinese press history: Macao press history 1557-1840. Beijing: Instituto Cultural do Governo da R.A.E. de Macau/Social Sciences Academy Press (China).

Lee, K.-S. (2003). Copyright. In C. Heath (Ed.), Intellectual property law in Korea (pp. 121-150). London: Kluwer Law International.

Lehman, B. (1998, May 21). hfa51834.00: Intellectual property rights: the music and film industry: Hearing before the Subcommittee on International Economic Policy and Trade, 105th Cong. 51 (statement of Bruce Lehman, Assistant Secretary and Commissioner of Patents and Trademarks, Department of Commerce, pp. 11-33). Retrieved from: http://commdocs.house.gov/committees/intlrel/ Leitão, L. M. T. de M. (2011). Direito de autor. Coimbra: Almedina. Liang, L. (2011). Beyond representation: the figure of the pirate. In M. Biagioli, P. Jaszi \& M. Woodmansee (Eds.), Making and unmaking intellectual property: creative production in legal and cultural perspective (pp. 167-180). Chicago IL: University of Chicago Press.

Ljungstedt, A. (1836). An historical sketch of the Portuguese settlements in China and of the Roman Catholic Church mission in China. Boston, MA: J. Munroe \& Co.

Lo, S. S.-H. (2008). Political change in Macao. New York, NY: Routledge.

Lourenço, M. R. (2011). Macau, porto seguro para os cristãos-novos? Problemas e métodos sobre a periferia da Inquisição de Goa. Cadernos de Estudos Sefarditas, 10, 451-500.

Masson, G. (2000, April 8). IFPI seeks law enforcers' aid on piracy. Billboard, pp. 6, 78.

Matos, M. C. (2011). Imprensa de Macau: Imprensa periódica ocidental. In M. A. Espadinha (Ed.), DITEMA: Dicionário temático de Macau (Vol. 2, pp. 726-730). Macau: Universidade de Macau.

McClure, S. (1998, June 20). Combating piracy in Asia is still imperative. Billboard, pp. 66, 84 .

Megiani, A. P. T. (2006). Imprimir, regular, negociar: elementos para o estudo da relação entre coroa, Santo Ofício e impressores no mundo português (1500-1640). Anais de História de Além-Mar, 3, 231-250.

Mendes, C. A. (2013). Portugal, China and the Macau negotiations, 1986-1999. Hong Kong: Hong Kong University Press.

Mertha, A. (2005). The politics of piracy: intellectual property in contemporary China. Ithaca, NY; London: Cornell University Press. 
Metalitz, S. J. (1998, May 21). hfa51834.00: Intellectual property rights: the music and film industry: Hearing before the Subcommittee on International Economic Policy and Trade, 105th Cong. 51 (statement of Steven J. Metalitz, Vice President and General Counsel, IIPA, pp. 41-58). Retrieved from: http://commdocs.house.gov/committees/intlrel/

Mok, D. (2000, January 15). Macau piracy may slow: handover to China sparks mixed feelings. Billboard, pp. 48, 70.

Monteiro, A. N. (2011). Macau e a presença portuguesa seiscentista no Mar da China: interesses e estratégias de sobrevivência (Doctoral dissertation). Retrieved from: http://hdl.handle.net/10316/18493.

Murray, L. J., Piper, S. T. \& Robertson, K. (2014). Introduction. In L. J. Murray, S. T. Piper \& K. Robertson (eds.) Putting intellectual property in its place: rights discourses, creative labor, and the everyday (pp. 1-14). New York, NY: Oxford University Press. doi:10.1093/acprof:oso/9780199336265.001.0001

Neuwirth, R. J. \& Min, L. (2012). Macau S.A.R. In R .M. Hilty \& S. Nérisson (Eds.), Balancing copyright: a survey of national approaches (pp. 645-675). Berlin: Springer.

Oliveira, J. C. (1997). A localização dos actos normativos emanados da República Portuguesa. Boletim da Faculdade de Direito da Universidade de Macau, 4, 205-217.

Papovich, J. (2000, July 19). Serial No. 106-173: Costs of internet piracy for the music and software industries: Hearing before the Subcommittee on International Economic Policy and Trade, 106th Cong. 68. (statement of Joseph Papovich, Assistant U.S.T.R for Services, Investment, and Intellectual Property, pp. 8-20). Retrieved from: https://www.gpo.gov/fdsys/pkg/CHRG-106hhrg68958/pdf/CHRG-106hhrg68958.pdf .

Patterson, L. R. (1968). Copyright in historical perspective. Nashville, TN: Vanderbilt University Press.

Penalva, E. (2007). Contradictions in Macao. Bulletin of Portuguese-Japanese Studies, 14, 7-20.

Pereira, A. L. D. (2008). Direitos de autor e liberdade de informação. Coimbra:

Almedina.

Pereira, F. G. (1995). Portugal, a China e a 'Questão de Macau'. Macau: Instituto Português do Oriente.

Pina-Cabral, J. de (2002). Between China and Europe: person, culture, and emotion in Macao. London: Continuum.

Pina-Cabral, J. de (2003). Guerreiros da nova era: Macau na encruzilhada colonial. Brasília: Departamento de Antropologia, Universidade de Brasília.

Pires, B. V. (1991). Origins and early history of Macau. In R. D. Cremer (Ed.), Macau: city of commerce and culture: continuity and change (2nd ed., pp. 7-21). Hong Kong: API Press.

Pottage, A. \& Sherman, B. (2013). On the prehistory of intellectual property. In H. Howe \& J. Griffiths, J. (Eds.), Concepts of property in intellectual property (pp. 1128). Cambridge, UK: Cambridge University Press. doi:10.1017/CB09781107300880 
Rebello, L. F. (1973). Visita guiada ao mundo do direito de autor. Porto: Ordem dos Adgovados.

Richardson, B. (1998, May 21). hfa51834.00: Intellectual property rights: the music and film industry: Hearing before the Subcommittee on International Economic Policy and Trade, 105th Cong. 51 (statement of Bonnie Richardson, Vice President for Trade and Federal Affairs, MPAA, pp. 34-38). Retrieved from:

http://commdocs.house.gov/committees/intlrel/

Rodrigues, G. A. (1980). Breve história da censura literária em Portugal. Retrieved from: http://cvc.instituto-camoes.pt/conhecer/biblioteca-digital-camoes/estudosliterarios-critica-literaria/40-40/file.html

Saldanha, A. V., Wu Z. \& Jin G.P. (2004). As "Chapas Sínicas", a história de Macau e as seculares relações luso-chinesas. Administração, 66, 1275-1300.

Samuels, E. (2000). The illustrated history of copyright. New York, NY: St. Martin's Press.

Santos, B de S. \& Gomes, C. (1998). Macau: o pequeníssimo dragão. Porto: Afrontamento.

Sena, T. (2008). Macau's autonomy in Portuguese historiography, 19th and early 20th centuries. Bulletin of Portuguese-Japanese Studies, 17, 79-112.

Sherman, B. \& Bently, L. (1999). The making of modern intellectual property law: the British experience (1760-1911). Cambridge, UK: Cambridge University Press.

Silva, C. N. da (2015). A dimensão imperial do espaço jurídico português: formas de imaginar a pluralidade nos espaços ultramarinos, séculos XIX e XX. Rechtsgeschichte - Legal History Rg, 23, 187-205. doi:10.12946/rg23/187-205

Silveira, J. N. (1991). Subsídios para a história do direito constitucional de Macau: 1820-1974. Macau: Instituto Português do Oriente.

Souza, G .B. (1986). The survival of empire: Portuguese trade and society in China and the South China Sea, 1630-1754. New York, NY: Cambridge University Press.

Su C. (1996). The printing presses of the London Missionary Society among the Chinese (Doctoral dissertation). Retrieved from:

http://discovery.ucl.ac.uk/1317522/1/243966.pdf

Tang K. (2016). Setting off from Macau: essays on Jesuit history during the Ming and Qing dynasties. Leiden; Boston, MA: Brill.

Tanzer, A. (1998, September 7). Tech-savvy pirates. Forbes. Retrieved from: www.forbes.com/global/1998/0907/0111018a.html

Teixeira, M. (1991). The Church in Macau. In R. D. Cremer (Ed.), Macau: city of commerce and culture: continuity and change (2nd ed., pp. 39-49). Hong Kong: API Press.

Tengarrinha, J. (2013). Nova história da imprensa portuguesa das origens a 1865. Lisboa: Temas e Debates/Círculo de Leitores.

The Economist (1998, January 22). Software piracy: better than the real thing. Retrieved from: www.economist.com/node/603607 
The Law Reform Commission of Hong Kong (1993, November). Report on Reform of the Law Relating to Copyright (Topic 22). Retrieved from:

http://www.hkreform.gov.hk/en/docs/rcopyright-e.pdf

Treverton, G. F., Matthies, C., Cunningham, K. J., Goulka, J., Ridgeway, G. \& Wong, A. (2009). Film piracy, organized crime, and terrorism. Santa Monica, CA: RAND Corporation.

Tsang, A. (1998, May 16). Pirates plunder new territory in post-handover blitz [Supplement: Asia Pacific quarterly]. Billboard, pp. AP2, AP12.

Valenti, J. (2003a, March 13). hju85643.000: International copyright piracy: a growing problem with links to organized crime and terrorism: Hearing before the Subcommittee on Courts, the Internet, and Intellectual Property, 108th Cong. 85. (statement of Jack Valenti, President and CEO, MPAA, pp. 44-59). Retrieved from: http://commdocs.house.gov/committees/judiciary/

Valenti, J. (2003b, July 16) hfa88392.000: Intellectual property crimes: are proceeds from counterfeited goods funding terrorism? Hearing before the Committee on International Relations, 108th Cong. 88. (prepared statement by Jack Valenti, President and CEO, MPAA, pp. 166-189). Retrieved from:

http://commdocs.house.gov/committees/intlrel/

Viana, V. T. (2000). An economic analysis of the criminal behaviours in Macau. In S. S. Chan (Ed.), Leading issues of the Macau economy (pp. 213-224). Macau: Macau Foundation.

Vines, S. (1998, May 3). Hong Kong is losing its phoney war. The Independent, 16.

Wesley-Smith, P. (1994). The sources of Hong Kong law. Hong Kong: Hong Kong University Press.

White, A. (1998, June 6). Two IFPI officers detail the extent of business piracy problems in Asia. Billboard, pp. 64, 70.

Wilkinson, A. S. (2010). Introductory essay: publishing on the Iberian Peninsula at the beginning of the golden age, 1472-1600. In A. S. Wilkinson (Ed.), Iberian books: books published in Spanish or Portuguese or on the Iberian Peninsula before 1601/Libros ibéricos pulicados en español o portugués o en la Península Ibérica antes de 1601 (pp. xiv-xxiii). Leiden; Boston, MA: Brill.

Witek, J. W. (1997). Com o Japão em vista: Alexandre Valignano e a abertura do Colégio de Macau. (C. Martins, P. Catalão \& J. Nogueira, Trans.). Revista Cultura, 30(1), 17-29.

Woods, A. (2003). Category III films and VCDs: the failure of deterrence in the Copyright Ordinance of Hong Kong. Vanderbilt Journal of Transnational Law, 36, 1073-112.

WTO (World Trade Organization) (2001, February 19). WT/TPR/G/82: Trade Policy Review Macau, China: Report by the Government. Retrieved from:

https://docs.wto.org/dol2fe/pages/FE Search/ExportFile.aspx?id=68293\&filename= Q/WT/TPR/G82.pdf 
Wu Z. (1999). Segredos da sobrevivência: história política de Macau. Retrieved from: http://www.macaudata.com/macaubook/book091/index.html.

Yang, Z. (2000). China and the international protection of copyright. Journal of World Intellectual Property, 3, 197-209. doi:10.1111/j.1747-1796.2000.tb00123.x

Youm, K. H. (1999). Copyright law in the Republic of Korea. Pacific Basin Law Journal, 17, 276-300.

Yu, P. K. (2000). From pirates to partners: protecting intellectual property in China in the twenty-first century. American University Law Review, 50, 131-243.

Zhang, J. (2007). Pushing copyright law in China: a double-edged sword. DePaul Journal of Art, Technology \& Intellectual Property Law, 18, 27-77. 


\title{
ENDNOTES
}

\begin{abstract}
${ }^{1}$ The history of copyright law in Macau is still a largely uncharted territory, although I must acknowledge the extremely useful insights provided by Gonçalo Cabral who has been writing about Macau intellectual property law since the late 1990s (Cabral, 1999; 2003; 2010a; 2010b).

${ }^{2}$ Código civil portuguez. Carta de Lei de 1 de Julho de 1867, published in Diário de Lisboa between 5 August (n.o 173) and 21 September (n.o 213), [1867 Civil Code]. For the troubled history of its publication see Cruz (1967) pp. 28-29 fn 1.
\end{abstract}

${ }^{3}$ Decreto tornando applicável às províncias Ultramarinas o código civil, com algumas modificações (11 November 1869), published in Diário do Governo, n.o 265, 20 November, [Decreto 18.11.1869]. Available online at: http://legislacaoregia.parlamento.pt.

${ }^{4}$ U.S. Trade Representative 1998 Special 301 Report (May 1).

${ }^{5}$ For the functioning of copyright as rule (i.e. as reason for action) and rhetoric (i.e. as symbol and discourse) see Murray, Pipper and Robertson (2014). For the claim that 'the evolution of copyright law in Macau has been and continues to be influenced by external forces' see Neuwirth and Min (2012, p. 646).

${ }^{6}$ Only three books are known to have been printed in Macau with metal movable types, all dealing with the Japanese mission, these were Christiani Pueri Institutio by loanne Bonifacius, S.J. in 1588; De missione legatorum laponensium ad Romanam curia by Alessandro Valignano, S.J. and Duarte de Sande, S.J. in 1590; and Arte Breve, da lingoa lapoa by João Rodrigues 'Tçuzu', S.J. in 1620 (Barreto, 2006, pp. 323 f.).

${ }^{7}$ Xylography (i.e. woodblock printing) seems to have been more commonly used in the Jesuit mission to China, including for books in Western languages (Boxer, 1993, p. 189). The reasons for the popularity of woodblock printing vis-à-vis printing with movable metal types (typography) in China up to the nineteenth century are not entirely clear. The commonly held assumption that this was due solely to the cost of setting up a fully workable set of types, given the large number of Chinese characters, is challenged by Chow (2007) pointing to other factors such as the type of paper produced in China at the time and the low labour costs involved in hiring skilled wood carvers.

${ }^{8}$ E.g. Apologia de la Compania de Jesus de Japon y China by Alessandro Valignano, S.J. written mainly in Macau and published in Nagasaki, 1598 (Barreto, 2006, pp. 350-351); Tian Zhu Shi Lu by Michele Ruggieri (et. al. ?) finished in Macau and published in Zhaoqing, 1584 (Barreto, 2006, pp. $316 \mathrm{f}$. ); the Latin translation of Confucius' Da Xue began at Macau in 1582 and partly published in Rome in 1593 (Barreto, 2006, p. 316); Libro y relacion de las grandezas del reyno de la China of unknown attribution, date and place of publication but probably published in Spain around 1586 1587 based on information gathered at Macau (Barreto, 2006, pp. 339-341); Relação da magestosa, misteriosa, e notavel acclamaçam, que se fez a Magestade d'El Rey Dom Joam o IV nosso Senhor na Cidade do nome de Deos do grande Imperio da China, \& festas que se fizeram pelos Senhores do Governo publico, \& outras pessoas particulares by João Marques Moreira published in Lisbon, 1644, which is probably the first book published in Portugal solely about Macau (Braga, 1963, p. 86).

\footnotetext{
${ }^{9}$ This did not prevent some of this information to 'leak' to foreign rival merchants who later printed it elsewhere (Barreto, 2006, p. 307).

${ }^{10}$ An unfinished work of unknown attribution, date and location, but thought to be a collective work, written between 1580 and 1588 in Macau and Zhaoqing (Barreto, 2006, pp. 318 ff.; see also Barreto, 2002, for the debates surrounding the attribution of the text to Michele Ruggieri, S.J. and Matteo Ricci, S.J.).
} 
${ }^{11}$ A facsimile version of the Vocabulário appeared in print, edited by John W. Witek, S.J. in 2001 (Barreto, 2002).

${ }^{12}$ On the use of privileges granted to printers, booksellers and occasionally writers in Portugal see, in English, Armstrong (1990, pp. 7 f.). In Portuguese see e.g. Tengarrinha (2013) pp. 265-269; and Megiani (2006). Also in Portuguese, a short catalogue published by the Portuguese National Library still stands as one of the most useful guides to the primary sources on the history and prehistory of copyright (Biblioteca Nacional, 1994) to which the still unfinished section on Portugal at the L.

Bently \& M. Kretschmer (eds.) Primary Sources on Copyright (1450-1900), www.copyrighthistory.org database, edited by Patrícia Akester and Victor Drummond will certainly be welcomed as a precious addition.

${ }^{13}$ For a short, but remarkably clear history of literary censorship in Portugal, see Rodrigues (1980). On the role of the Inquisition in the regulation of printing see Bethencourt (2009).

${ }^{14}$ Although 1487 - when the Hebrew version of the Pentateuch was published in Faro - remains the safest date, it is possible that an earlier publication had occurred in Lisbon the year before Certificado de indulgências de Inocêncio VIII (http://purl.pt/22009). (Wilkinson, 2010, p. xiv).

${ }^{15}$ Inquisitorial censor at Évora.

16 "Carta de Privilégio para a Impressão de Livros" concedida por D. João III a Balatasar Dias em 1537. Torre do Tombo, livro 23, folha 17 (non vide). My translation from the transcription retrieved from: http://www.unicamp.br/iel/memoria/base_temporal/Historia/acpXVI_n1.htm.

${ }^{17}$ The institutionalisation of censorship in no way inaugurated the repression of ideas and the persecution of those expressing or holding them. Since the fourteenth century the Church had used its power, as Rodrigues (1980) puts it, to condemn and burn not only books but also their makers (p.13). See Rodrigues (1980, ch 1, ch 2) for an overview of different forms of censorship in Portugal from the fourth century to the 1970s.

${ }^{18}$ See Bethencourt (2009, pp. 226-230) for a more detailed account and a very useful overview of the primary and secondary sources on the Inquisitorial control of the book in Portugal (1551-1819).

${ }^{19}$ Megiani (2006, p. 241) mentions a royal privilege granting the Society of Jesus a monopoly over printing in the East, but does not indicate dates or a specific source.

${ }^{20}$ Although Montalto de Jesus (1902) is quick to state, the then official line, that irrespective of the emperor's 'grace or concession', Portuguese sovereignty was 'founded on the right of conquest' ( $p$. 19), the gentler version still proves influential (Silveira, 1991, p. 9; Caniato, 2004, pp. $117 \mathrm{ff.}$; Godinho, 2007, p. 1 fn1; Cardinal, 2008, p. 639).

${ }^{21}$ Whose work Montalto de Jesus (1902) takes pains to discredit; albeit with little success (pp. 21 28). For more recent contributions to the debate paying particular attention to Chinese sources, see Cheng (1999 pp. 22-30); Wu (1999, ch 1, ch 3.3) and Hao (2011 ch 1).

${ }^{22}$ See also Pires (1991, pp. 7-10), Gunn (1996, pp. 15-18) and Wu (1999, ch 2.2) emphasising the importance of bribes paid to the local Guandong officials, before morphing into a more institutionalised system of an annual ground rent paid to Chinese authorities (foro do chão) in the 1570s.

${ }^{23}$ It is precisely by missing this need for ambiguity and flexibility in negotiating a position amidst various centres of power - on the Portuguese side: Lisbon and Goa; on the Chinese side: Beijing and Guangzhou; and later (1580-1680) Madrid and Manila, when the Habsburgs reigned over Spain and Portugal - that Montalto de Jesus' critique of Ljungstedt's thesis (see n21 supra) seems most misguided. Particularly when he writes: 'Nor would the Portuguese have incurred the heavy outlay they did in building the city, had they not been quite sure of their rights to do so' (Jesus, 1902, p. 19). 
${ }^{24}$ During most of the pre-colonial period (1583-1849) the locally elected Senado was the highest local authority, with judicial and administrative powers as well as a diplomatic role in its relation with Chinese authorities. In this later regard the Procurador (municipal attorney) whose role doubled as member of the Senado and as local mandarin, played a pivotal role not only in the administration of justice but also as a privileged interlocutor between the local Portuguese and Macanese communities and the Chinese authorities. (Saldanha, Wu \& Jin, 2004, pp. 1279-1287; Wu, 1999 , ch 2.1) The role of the Senado is aptly summarised by Barreto (2006) 'the Senado and its Procurador perform a constant exercise of power within and between Ming China and the Portuguese Crown, knowing at all moments how to negotiate the limits and possibilities of Macau's residents (moradores).' (p. 155: my translation)

${ }^{25}$ The establishment of The Royal Censorial Court (Real Mesa Censória) in 1768 instituted a new model of censorship eliminating the three-layered system and creating a centralised royal court of censors. This move towards a more secular model is accompanied by an increase of focus on repression of undesirable political ideas rather than religious ones. This model was short-lived as the three-layered system, mainly controlled by the Church, was reinstituted in 1794 under Queen D. Maria I (Rodrigues, 1980, pp. 31-37).

${ }^{26}$ As Pina-Cabral (2002) explains the word 'incidentes' (incidents, troubles) has acquired a specific local meaning, especially among the Macanese, to refer to what he wonderfully translates as 'processes of liberation of the energy that has accumulated over periods of apparent peace and prosperity during which the central contradiction continues to operate but in a repressed fashion' (p. 9). Although it is most commonly used to identify events of a greater magnitude, it is perhaps not a coincidence that Jack Braga (1963) occasionally uses the word 'incident' to describe the events mentioned in the text (pp. 66, 68, 69, 110). I shall use 'incidente' along the text to alert the reader to the recurrence of periods of eruption and accommodation hinged upon internal contradictions in the city's metabolism.

${ }^{27}$ Regrettably, while Braga's (1963) orientalist account praises the kindness of Portuguese authorities in turning a blind eye to these activities - while lamenting the ungentlemanly lack of recognition in British sources - he reads the complacency of what he calls the otherwise 'truculent mandarins' (p. 65) as a consequence of rampant corruption in the Chinese Qing administration.

${ }^{28}$ It should be noted that in the wake of the first Napoleonic invasion (1807-1814) Portugal had become a de facto British protectorate.

${ }^{29}$ During the Qing dynasty (1644-1911) this was the office of the sub-prefect - with civil and military capacity - situated in Qianshan in the close vicinity of Macau. This sub-prefect was in charge of dealing with affairs related to Macau, and reported directly to Guangzhou. The local Mandarin residing in Macau (district magistrate) was under his dependence. (Saldanha, Wu \& Jin, 2004).

${ }^{30}$ While it is common to speak, not unreasonably, of this period as one of mixed Sino-Portuguese jurisdiction (Hespanha, 1995; Pereira, 1995, pp. 22-27) it is important not to forget the fluidity and uncertainty that marked the co-presence of forces irradiating from China and Portugal and carefully negotiated by the Senado (Barreto, 2006, pp. 199-221). Even if some forms of administration of the city's affairs, including the dispensation of justice, fell onto Portuguese hands this exertion of sovereignty was always shared with and consented by Chinese authorities (Santos \& Gomes, 1998, pp. 221-227; Wu, 1999, ch 3.3; Souza, 1986, ch 8).

${ }^{31}$ Afonso and Pereira (1998, pp. 28-31) and Wu (1999, ch 3.3) offer brief synopses of situations where this supposed division of power between Portuguese and Chinese authorities was notably overlooked.

${ }^{32}$ Constituição política da Monarchia Portugueza decretada pelas Cortes Geraes Extraordinárias e Constituintes reunidas em Lisboa no anno de 1821 (23 September 1822). Retrieved from: http://purl.pt/6926. 
${ }^{33}$ Such freedom had already been recognised in art. 8 of the provisional constitution (Bases da Constituição da Monarquia Portuguesa) of 1821 (Diário das Cortes Geraes Extraordinárias da Nação Portugueza (1821) n.o 30, Sessão de 9 de Março. Decreto das Bases da Constituição (pp. 232-235). Available online at: http://debates.parlamento.pt); and in art. 1 of the law regulating the freedom of press (Decreto de 4 de Julho de 1821, published in Diário do Governo between 26 July (n.o 175) and 28 July (n.o 177). Available online at: http://hemerotecadigital.cm-

lisboa.pt/Leisdelmprensa/Leisdelmprensa.htm) as well as in the Spanish Constitution of 1812 that the provisional revolutionary government had decided to bring immediately into force on November 11, 1820, while the Bases da Constituição were being discussed (Tengarrinha, 2013, p. 347).

${ }^{34}$ Citizenship was restricted to men and recognised on the basis of jus sanguinis by which only the sons of Portuguese men or illegitimate sons of Portuguese women would be entitled to citizenship, subject to a territorial caveat which restricted citizenship to men either born or residing in Portuguese territories (art. 21). The rule included slaves freed by their owners under a 'carta de alforria' (art. 21, iv). Foreigners were entitled to apply for naturalisation (art. 22).

${ }^{35}$ By then, and even before the liberal turn, Portuguese Catholic priests at the College of St. Joseph had been granted royal permission to set up a printing press for their missionary work in Macau. When, in 1819, the letter arrived, from Rio de Janeiro (Brazil) where the Portuguese Court had exiled during the Napoleonic invasion, the College had already been producing xylographic books since 1815 with unofficial permission by local authorities (Braga, 1963, p. 69; with translations of the relevant correspondence in pp. 135-137).

${ }^{36}$ Braga (1963) notes that the Gazeta would sometimes publish extracts from overseas newspapers (p. 81) a practice that seems to have been common in English periodicals of the period (pp. $89 \mathrm{ff}$.). It seems that a study of local editorial practices of the period is still to be done, but it would be extremely interesting to investigate whether ideas of literary property in any way shaped these practices of appropriation; as well as an analysis of the protocols linking editors, publishers, writers and translators.

${ }^{37}$ Between 1827 and 1844 the printing press from which the Canton Register came out, would seasonally migrate between Guangzhou and Macau, before it moved to Hong Kong (Braga, 1963, p. 88,90 fn 110, p. 133).

${ }^{38}$ According to Lam (2011) sixty years had to go by until another Chinese newspaper would be printed in Macau. This was the Chinese version of Echo Macaense (Jul 1893-Sep 1899) - also published in Portuguese (p. 734).

${ }^{39}$ Carta Constitucional da Monarchia Portugueza decretada, e dada pelo Rei de Portugal e Algarves D. Pedro, Imperador do Brasil (29 April 1826). Retrieved from: http://purl.pt/11484

${ }^{40}$ Constituição política da Monarchia Portugueza (4 April 1838). Retrieved from: http://purl.pt/725.

${ }^{41}$ Carta de Lei de 3 de Agosto de 1850, published in Diário do Governo, n. 187, 10 August, pp. 513530. Available online at: http://hemerotecadigital.cm-

lisboa.pt/Leisdelmprensa/Leisdelmprensa.htm.

${ }^{42}$ In 18 May, 1839 Garrett had presented a bill (Diário da Câmara dos Deputados (1839) n.으. 35. Sessão de 18 de Maio. Projecto de Lei sobre a propriedade litteraria e artística ... pelo Deputado J.B. de Almeida Garrett (pp. 568-575). Available online at: http://debates.parlamento.pt) meant to implement and regulate the protection of author's enshrined in the Vintista constitution (art. 23.4) which in turn had also been put forward by him (Diário das Cortes Geraes Extraordinárias, $e$ Constituintes da Nação Portugueza (1837) n.o 120 , Sessão de 23 de Junho, p. 166. Available online at: http://debates.parlamento.pt). The bill was passed in the lower house of the parliament on Februrary 8, 1841 (Diário da Câmara dos Deputados (1841) n.o 6. Sessão de 8 de Fevereiro, pp. 71 80. Available online at: http://debates.parlamento.pt).

${ }^{43}$ Where the inquisitorial autos de fé had usually taken place. 
${ }^{44}$ Tellingly, Alexandre Herculano - who would later become the most notable critic of Garrett's initiatives (Ferraz, 2003; Carnaxide, 1918, pp. 34-58) and who was also a member of parliament in 1839 - voted in favour of the bill. Later acknowledging that, at the time, he did not pay much attention to Garrett's proposal (Herculano, 1851, pp. 59-60).

${ }^{45}$ Decreto (8 July 1851), published in Diário do Governo, n. 167, 18 July. Available online at: http://hemerotecadigital.cm-lisboa.pt/DireitodeAutor/DireitodeAutor.htm [1851 Act]

${ }^{46}$ Convenção Litterária. Carta de confirmação e ratificação (12 June 1851), published in Diário do Governo, n.o 245, 17 October. Available online at: http://legislacaoregia.parlamento.pt.

47 The institution of literary property was in no way sufficient to curb censorship, as it continued very strongly in the country until 1974 (Rodrigues, 1980).

${ }^{48}$ Lei da propriedade literária, scientífica e artística. Decreto n.o 13:725 (27 May 1927), published in Diário do Governo, n.o 114, Série I, 3 June, pp. 902-114. Available online at: http://hemerotecadigital.cm-lisboa.pt/DireitodeAutor/DireitodeAutor.htm. [1927 Copyright Act]

${ }^{49}$ Tratado de Amizade e Comércio entre Portugal e a China 1887.

50 The instability that marked this period makes it very hard to establish whether the act ever came into force in Macau. Even at a rather abstract level of legal technicality, the very rapid succession of different constitutions and with them different colonial policies, makes the question a tricky one. With the 1838 Setembrista Constitution, colonial policy broke away from the traditional policy of uniformity, by which all legislation enacted in Portugal would come into force, without restrictions, in the overseas territories. Although the Setembrista was no longer in force when the act was passed - having been replaced by the Vintista Constitution, which followed the traditional policy of uniformity - an 1852 Constitutional amendment adopted a more particularistic policy which allowed local legislation to be enacted and national legislation to be extended according to the perceived 'local needs' (Hespanha, 1995; Silveira ,1991).

51 Japan had its first copyright statute in 1869 (Ganea, 2005, p. 3), Korea in 1908 (Lee, 2003, p. 121) or 1910 (Youm, 1999, p. 281) the same year as China (Yang 2000, p. 198). As for Hong Kong, while the 1847 Colonial Copyright Act (Act to Amend the Law Relating to the Protection in the Colonies of Works Entitled to Copyright in the UK, 22 July 1847) might, at least nominally, have applied to the newly established colony, it seems be possible that earlier copyright legislation might have come into force through the Supreme Court Ordinances (No 15 of 1844; No 6 of 1845 and No 2 of 1846) by which English law was extended in bulk to Hong Kong (Wesley-Smith, 1994, pp. 88-90). It should, however, be clear that little of the argument made in this paper lies on this particular fragment of copyright history.

52 In his commentary to the 1867 Civil Code, Dias Ferreira (1871) criticised the measure in the following terms: 'The code should not have obliged the author or proprietor of the work, wherever it came to be published, even if in the overseas provinces, to send the copies at his own expense to Lisbon, and to request the relevant proof of delivery' (p. 134, commentary to arts. 603-606: my translation) suggesting instead that they should have been allowed to deliver the work to the relevant local authority.

${ }^{53}$ Berne Convention for the Protection of Literary and Artistic Property 1886 [Berne Convention]

${ }^{54}$ This is mentioned in art. 1 of the decree that declared the accession to the Berlin Act (1908) of the Berne Convention (1886). Decreto com força de lei de 18 de Março, declarando a adesão de Portugal e suas colónias à convenção de Berne para a protecção da propriedade literária e artística (1911), published in Diário do Governo, n.o 67, 23 March, pp. 1245-1250. Available online at: http://hemerotecadigital.cm-lisboa.pt/DireitodeAutor/DireitodeAutor.htm. [Decree 18.3.1911]

${ }^{55}$ Berne Notification 207 of 12 May 1999. 
${ }^{56}$ This seems to have gone unnoticed by António Baptista de Sousa who published the first Portuguese treatise on copyright in 1918 - published under his noble rank of Visconde de Carnaxide - where he states that the Convention extended to the colonies (Carnaxide, 1918, p. 371).

${ }^{57}$ When the 1927 Copyright Act was extended to Macau, thus repealing the copyright provisions in the 1867 Civil Code, by Declaração de que o decreto n. $13: 725$ que promulgou e codificou disposições sôbre propriedade literária, scientífica e artística, deve ser publicado nos Boletins Oficiais das colónias (29 April 1930), published in Boletim Oficial da Colónia de Macau, n. 25, 21 June, pp. 477-493. Available online at: http://www.archives.gov.mo/pt/bo.

58 Portaria n. - 15:510: manda aplicar a todas as províncias ultramarinas o Decreto-Lei n.o 38:304, que aprovou a Convenção de Berna ... segundo o texto da revisão feita em Bruxelas a 26 de Junho de 1948 ... (20 August 1955), published in Boletim Oficial de Macau, n. 0 37, 10 September, pp. 587624. Available online at: http://www.archives.gov.mo/pt/bo.

${ }^{59}$ According to MP Francisco Salgado Zenha, who put forward the bill that would eventually shorten the transitional period set out in the 1966 Copyright Code that repealed the perpetuity rule, this included all works whose authors had died after January 5, 1872. Diário da Assembleia da República (1979) n.o 84, Série I, Sessão de 14 de Julho. Projecto de lei n.o 192/l: Regime jurídico do direito de autor (pp. 3166-3167). Available online at: http://debates.parlamento.pt

60 See n57 supra.

${ }^{61}$ Código do direito de autor. Decreto-Lei n.o 46980 (27 April 1966), published in Diário do Governo, n.o 99, Série I, pp. 630-647. Available online at: http://hemerotecadigital.cm-

lisboa.pt/DireitodeAutor/DireitodeAutor.htm. [1966 Copyright Code]

62 Portaria n. 0 679/71 de 7 de Dezembro: torna extensivo ao ultramar o Decreto-Lei n.o 46980 que aprova o Código do Direito de Autor (1971), published in Boletim Oficial de Macau, n.o 2, 8 January 1972, pp. 37-54. Available online at: http://www.archives.gov.mo/pt/bo.

${ }^{63}$ Again according to Salgado Zenha (see $n 59$ supra), under the transitional period set out in the 1966 Copyright Code, works whose authors had died on or before December 31, 1941, would fall on the public domain on January 1, 1992. I.e. in relation to those deceased in 1941, according to the general rule; in relation to those deceased before that date, according to the twenty five year extension set out in the 1966 Copyright Code.

${ }^{64}$ Lei n.o 29/79 de 6 de Setembro: revogação do n.o 2 do artigo 37. o do Código do direito de autor (1979) published in Diário da República, n. 206. Série I, p. 2216.

${ }^{65}$ Declaração Conjunta do Governo da República Portuguesa e do Governo da República Popular da China sobre a Questão de Macau 1987.

${ }^{66}$ The actual wording used during Salazar's time was províncias ultramarinas (overseas provinces) Acto Colonial 1951 in an attempt to mask the colonial reality under the guise of a luso-tropicalist rethoric (Mendes, 2013, pp. 22 f.).

${ }^{67}$ Decreto de aprovação da constituição de 10 de Abril de 1976, published in Diário da República, n.o 86, Série I, pp. 738-775.

${ }^{68}$ Lei n.o 1/76 de 17 de Fevereiro: promulga o estatuto orgânico de Macau (1976), published in Diário da República, n. 40, Série I, pp. 327-336. Bilingual version published in Boletim Oficial de Macau, n.o 9 [suplemento], 28 February 1976, pp. 261-274.

${ }^{69}$ Rome Convention for the Protection of Performers, Producers of Phonograms and Broadcasting Organisations 1961. Ratified through Decreto do Presidente da República, n. $0168 / 99$ de 22 de Julho (1999), published in Diário da República, n.o 169, I Série-A.

70 Lei n. $01 / 80$ de 12 de Agosto: protecção contra a reprodução ilícita de fonogramas (1980), published in Diário da República, n.o 185, Série I, pp. 2138-2140. 
${ }^{71}$ Código do direito de autor e dos direitos conexos. Decreto-Lei n.o 63/85 de 14 de Março (1985), published in Diário da República, n.o 61, Série I, pp. 662-689. Available online at: http://hemerotecadigital.cm-lisboa.pt/DireitodeAutor/DireitodeAutor.htm.

72 Lei n. - 4/85/M: assegura a protecção contra a reprodução ilícita de fonogramas e de videogramas (1985), published in Boletim Oficial de Macau, n. o 47, 25 November, pp. 3346-3347.

${ }^{73}$ Article 8 of The Basic Law of the Macau SAR stated that all pieces of legislation previously in force in Macau should remain to be so. This raised the question of knowing whether this provision referred to all legislation - including Portuguese legislation extended to the territory - or only legislation that had been locally enacted. See Oliveira (1997) Ascensão (1997, p. 7); and Santos and Gomes (1998, pp. 77-85).

${ }^{74}$ Regime do direito de autor e direitos conexos. Decreto-Lei n.o 43/99/M de 16 de Agosto (1999), published in Boletim Oficial de Macau, n.o 33, Série I, pp. 2890-2951.

75 International Intellectual Property Alliance 2001 Special 301 Report (February 16).

${ }^{76}$ Decreto-Lei n. 17/98/M de 4 de Maio: aprova medidas de proteç̧ão da violação empresarial de direitos de propriedade intelectual sobre fonogramas, videogramas e programas de computador (1998), published in Boletim Oficial de Macau, n.o 18, Série I, pp. 491-498. The day after the bill was passed (and even before its publication), the United States Trade Representative in its Special Report 301 'welcome[d] recent assurances from the Government of Macau to address these issues, as well as new legislation to take effect May 1 that will license the import and export of compact discs and CD production equipment.'

77 U.S. Trade Representative 1999 Special 301 Report (April 30).

78 Decreto-Lei n. 0 51/99/M de 27 de Setembro: regula o comércio e indústria de programas de computador, fonogramas e videogramas (1999), published in Boletim Oficial de Macau, n. 039 , Série I, pp. 3583-3601.

79 U.S. Trade Representative 2000 Special 301 Report (May 1).

80 Lei 11/2001: cria os serviços de alfândega da Região Administrativa Especial de Macau da República Popular da China (2001), published in Boletim Oficial da RAEM, n. 32, Série I, 6 August, pp. 903-910.

81 U.S. Trade Representative 2002 Special 301 Report.

82 See e.g. U.S. Trade Representative 2003 Special 301 Report (May 1), p. 3

${ }^{83}$ Following a more cautious position that 'pirates may not be triad members, but they can buy protection from triads' White (1998, p. 70). This was echoed in the report of the U.S. Bureau of East Asian and Pacific Affairs (2001) that also pointed out the coincidence of the crackdown on piracy in with a 'general decline in Triad violence' in the period right after the handover.

${ }^{84}$ As Pina-Cabral (2002) points out this sort of negotiation between various sources of power, while not being unique to Macau, forms an essential part of 'the normal condition of the city' and may take various forms either as a 'recreated pact of invisibility' or as frontal negotiations through meetings between official authorities and triad leaders (pp. $210 \mathrm{ff}$ ).

84 The anecdote about the infamous head of the $14 \mathrm{~K}$ triad, Broken Tooth (Wan Kuok-Koi, aka Pan Nga Koi) having sent a warning to those selling unlicensed copies of the semi-biographic feature film Casino (1998) - in whose production he had been heavily involved (Colmey, 1998) - that 'if they did not "trash" the pirated versions of the movie, then they themselves would subsequently be "trashed" (Mertha, 2005, p. 161 fn 160), might prove an interesting starting point. 